ORNL/TM-12101

\title{
ORNL RESULTS FOR TEST CASE 1 OF THE INTERNATIONAL ATOMIC ENERGY AGENCY'S RESEARCH PROGRAM ON \\ THE SAFETY ASSESSMENT OF NEAR-SURFACE RADIOACTIVE WASTE DISPOSAL FACILITIES
}

\author{
David J. Thorne \\ Laura M. McDowell-Boyer \\ David C. Kocher \\ E. Kirk Roemer* \\ Craig A. Little
}

*Oak Ridge Institute of Science and Education

Published:

\footnotetext{
Prepared by

Oak Ridge National Laboratory

Pollutant Assessments Group

Grand Junction, Colorado

United States of America managed by

Martin Marietta Energy Systems, Inc.

for the

United States Department of Energy

under contract DE-AC05-84OR21400
} 
TABLE OF CONTENTS

FIGURES $\ldots \ldots \ldots \ldots \ldots \ldots \ldots \ldots \ldots \ldots \ldots \ldots \ldots, \ldots$

EXHIBITS $\ldots \ldots \ldots \ldots \ldots \ldots \ldots \ldots \ldots \ldots \ldots \ldots \ldots \ldots \ldots, v$

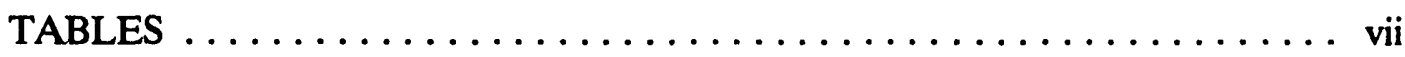

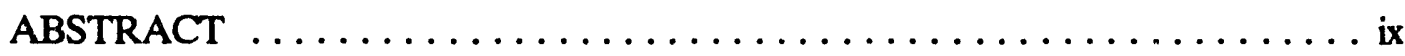

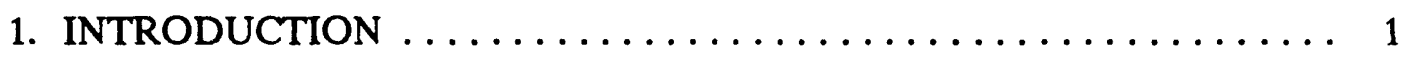

2. TEST CASE INPUT SPECIFIED BY THE IAEA $\ldots \ldots \ldots \ldots \ldots \ldots, 2$

2.1 REPOSITORY DESIGN AND SITE CHARACTERISTICS ..... 2

2.2 NUCLIDES AND INVENTORY $\ldots \ldots \ldots \ldots \ldots \ldots \ldots \ldots$

2.3 WASTEFORM $\ldots \ldots \ldots \ldots \ldots \ldots \ldots \ldots \ldots \ldots \ldots \ldots \ldots \ldots$

2.4 GEOSPHERE $\ldots \ldots \ldots \ldots \ldots \ldots \ldots \ldots \ldots \ldots \ldots \ldots \ldots \ldots$

2.5 EXPOSURE SCENARIOS $\ldots \ldots \ldots \ldots \ldots \ldots \ldots \ldots \ldots \ldots \ldots$

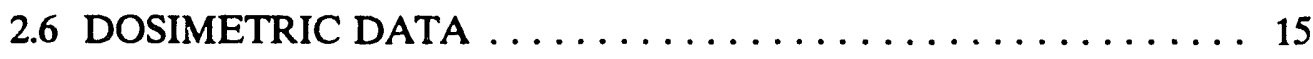

2.7 ADDITIONAL PARAMETER VALUES $\ldots \ldots \ldots \ldots \ldots \ldots \ldots \ldots$

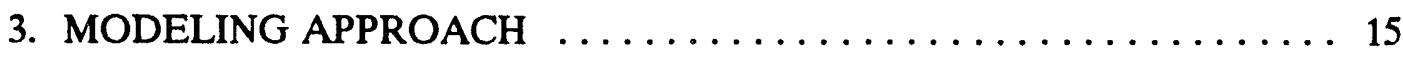

3.1 RELEASE RATE TO THE GEOSPHERE ............ 15

3.2 GROUNDWATER TRANSPORT $\ldots \ldots \ldots \ldots \ldots \ldots \ldots \ldots \ldots$

3.3 DETERMINATION OF DRINKING WATER AND

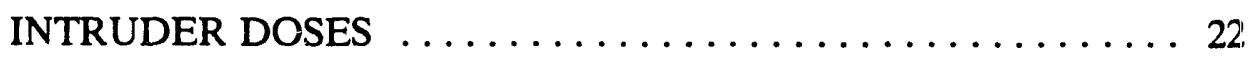

3.3.1 Exposure to Radionuclides in Drinking Water $\ldots \ldots 22$

3.4 EXPOSURE PATHWAYS FOR DIRECT INTRUSION INTO DISPOSAL UNITS $\ldots \ldots \ldots \ldots \ldots \ldots \ldots \ldots \ldots \ldots$

3.4.1 Exposure Scenarios and Exposure Pathways for Inadvertent Intruders $\ldots \ldots \ldots \ldots \ldots \ldots \ldots \ldots$

3.4.2 Dose Conversion Factors for Internal and External Exposure ........................ 24 
3.4.3 Models and Parameter Values for Intruder Exposure Pathways .................

3.4.4 Rn-222 Inhalation Dose $\ldots \ldots \ldots \ldots \ldots \ldots \ldots \ldots \ldots$

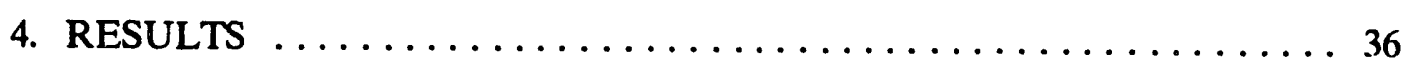

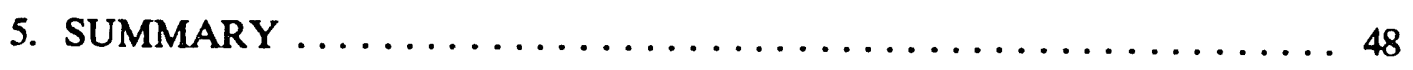

REFERENCES . . . . . . . . . . . . . . . . . . . 49

ACRONYMS AND INITIALISMS $\ldots \ldots \ldots \ldots \ldots \ldots \ldots \ldots \ldots \ldots \ldots \ldots$ 


\section{FIGURES}

1. Earth trench $\ldots \ldots \ldots \ldots \ldots \ldots \ldots \ldots \ldots \ldots \ldots \ldots \ldots$

2. Engineered vault $\ldots \ldots \ldots \ldots \ldots \ldots \ldots \ldots \ldots \ldots \ldots$

3. Schematic of well-water consumption outside the site boundary . . . . . 13

4. Schematic of house-building intrusion scenario $\ldots \ldots \ldots \ldots \ldots \ldots 14$

5. Kinetic release rate model for the earth trench and engineered vault $\ldots 18$

\section{EXHIBITS}

1. Results for NSARS Test Case 1T, Earth Trench: 1TR Release to Geosphere ......................... 37

2. Results for NSARS Test Case 1T, Earth Trench: 1TW Exposure to Man via Well Use . . . . . . . . . . . . . . . . . . . . . 39

3. Results for NSARS Test Case 1T, Earth Trench: 1TI1 Intrusion

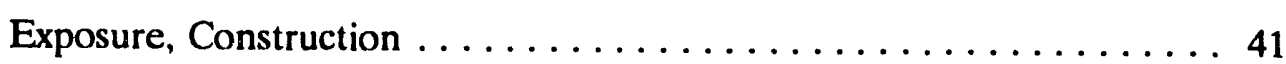

4. Results for NSARS Test Case 1T, Earth Trench: 1TI1 Intrusion Exposure, Agriculture . . . . . . . . . . . . . . . 42

5. Results for NSARS Test Case 1V, Engineered Vault: 1VR Release to Geosphere $\ldots \ldots \ldots \ldots \ldots \ldots \ldots \ldots \ldots \ldots \ldots \ldots \ldots \ldots \ldots \ldots$

6. Results for NSARS Test Case 1V, Engineered Vault: 1VW Exposure to Man via Well Use $\ldots \ldots \ldots \ldots \ldots \ldots \ldots \ldots \ldots \ldots \ldots$ 


\section{TABLES}

1. Defined parameter values for the earth trench concept (1T) ...... 5

2. Defined parameter values for the engineered vault design (1V) . . . . 6

3. Nuclides selected and their half-lives $\ldots \ldots \ldots \ldots \ldots \ldots \ldots$

4. Daughter nuclides and their half-lives $\ldots \ldots \ldots \ldots \ldots \ldots \ldots$

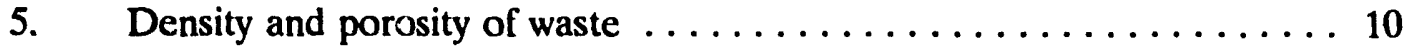

6. Defined properties of the aquifer $\ldots \ldots \ldots \ldots \ldots \ldots \ldots \ldots \ldots$

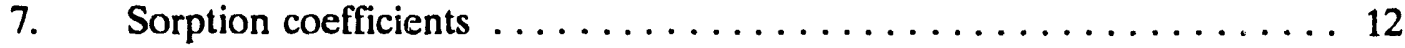

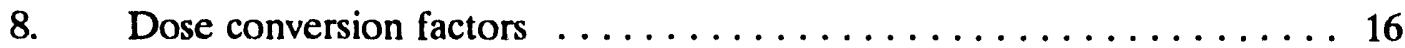

9. External dose-rate conversion factors for radionuclides uniformly

distributed in $15 \mathrm{~cm}$ of surface soil and uniformly distributed in

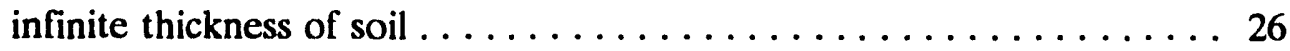

10. Elemental plant-to-soil concentration ratios in vegetables $\ldots \ldots \ldots \ldots 30$

1TR. Maximum release rate $\ldots \ldots \ldots \ldots \ldots \ldots \ldots \ldots \ldots \ldots$

1TW. Effective dose equivalent for drinking well water . . . . . . . . . 39

1TI1. Maximum doses from intrusion exposure, construction $\ldots \ldots \ldots \ldots 41$

1T12. Maximum doses from intrusion exposure, agriculture $\ldots \ldots \ldots \ldots \ldots 42$

1VR. Maximum release rate $\ldots \ldots \ldots \ldots \ldots \ldots \ldots \ldots \ldots \ldots \ldots$

1VW. Effective dose equivalent for drinking well water $\ldots \ldots \ldots \ldots \ldots \ldots$ 


\begin{abstract}
The International Atomic Energy Agency (IAEA) started the Coordinated Research Program entitled "The Safety Assessment of Near-Surface Radioactive Waste Disposal Facilities." The program is aimed at improving the confidence in the modeling results for safety assessments (referred by the U. S. Department of Energy as performance assessments) of waste disposal facilities. The program has been given the acronym NSARS (Near-Surface Radioactive Waste Disposal Safety Assessment Reliability Study) for ease of reference. The purpose of this report is to present the ORNL modeling results for the first test case (i.e., Test Case 1) of the IAEA NSARS program.

Test Case 1 is based on near-surface disposal of radionuclides that are subsequently leached to a saturated-sand aquifer. Exposure to radionuclides results from use of a well screened in the aquifer and from intrusion into the repository. Two repository concepts were defined in Test Case 1: a simple earth trench and an engineered vault.

Test Case 1 modeling was performed independently by several research participants from various countries, and comparisons of the results were conducted by working groups consisting of the research participants. The comparisons of NSARS Test Case 1 may be obtained from the IAEA. This report only presents the modeling results obtained by Oak Ridge National Laboratory (ORNL) for IAEA NSARS Test Case 1.
\end{abstract}




\section{INTRODUCTION}

This report presents the methodology used to determine the groundwater transport of radionuclides, water ingestion doses, and intruder doses for the first test case of the International Atomic Energy Agency's (IAEA) research program entitled "The Safety Assessment of Near-Surface Radioactive Waste Disposal Facilities (NSARS)".

The IAEA NSARS research program is aimed at improving the confidence in the modeling results for safety assessments (referred to by the U.S. Department of Energy as performance assessments) of waste disposal facilities. Test Case 1 modeling was performed independently by research participants from various countries, and comparisons of the results were conducted by working groups consisting of the research participants. The comparisons of NSARS Test Case 1 may be obtained from the IAEA. This report presents only the modeling results obtained by Oak Ridge National Laboratory (ORNL) for IAEA NSARS Case 1.

Test Case 1 is based on near-surface disposal of radionuclides that are subsequently leached to a saturated-sand aquifer. Exposure to these radionuclides results from: 1) use of a well screened in the aquifer and 2) intrusion into the waste repository. Two disposal concepts are defined for Test Case 1: a simple earth trench (Case 1T) and an engineered vault (Case 1V).

The principal features analyzed in this report are:

- Near-field performance in terms of release (R) to the geosphere for wastes in an earth trench (1TR) and an engineered vault (1VR);

- Release from the near field, leading to transport through the aquifer and exposures to man via use of a well (W) for both the earth trench (1TW) and the engineered vault (1VW);

- Intrusion (I) into the earth trench facility as part of the construction of a house foundation and exposures both during the intrusion and later (1TT); such intrusions are not considered reasonable for the somewhat deeper, engineered repository. 


\section{TEST CASE INPUT SPECIFIED BY THE IAEA}

This section presents descriptions of the disposal environments, parameter values, nuclides of concern, and exposure scenarios provided by the IAEA for use in the modeling of Test Case 1.

\subsection{REPOSITORY DESIGN AND SITE CHARACTERISTICS}

The earth trench concept (1T) and the engineered vault design (1V) are shown in Figs. 1 and 2. The defined parameter values for the two concepts are given in Tables 1 and 2. For both repository designs, the length of the facility is assumed to be perpendicular to the direction of groundwater flow.

Sites for both concepts are in a temperate climate with annual precipitation of $1000 \mathrm{~mm}$, assumed to be uniform throughout the year, and uniform evapotranspiration of $400 \mathrm{~mm}$ during the year.

\subsection{NUCLIDES AND INVENTORY}

A range of nuclides has been chosen to explore the importance of half-life, sorption potential, decay chains, gaseous forms, and mode of exposure in determining repository performance. The nuclides and daughter nuclides selected, and their half-lives, are given in Tables 3 and 4.

The inventory for each design concept is arbitrarily set for time $t=0$ at $1 \mathrm{TBq}$ of each of the nuclides in Table 3 . The inventories of daughter nuclides (Table 4) are assumed absent at $t=0$. 
ORNL-DWG 93-5750

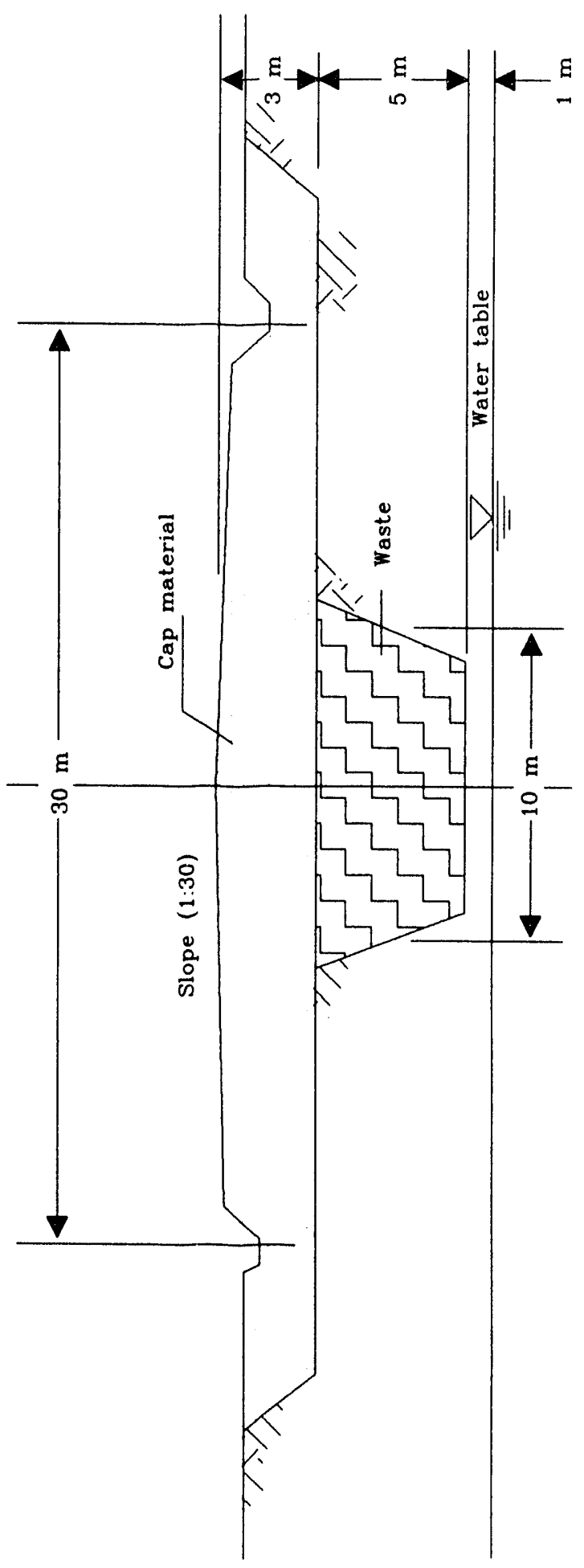

离

 
ORNL-DWG 93-5751

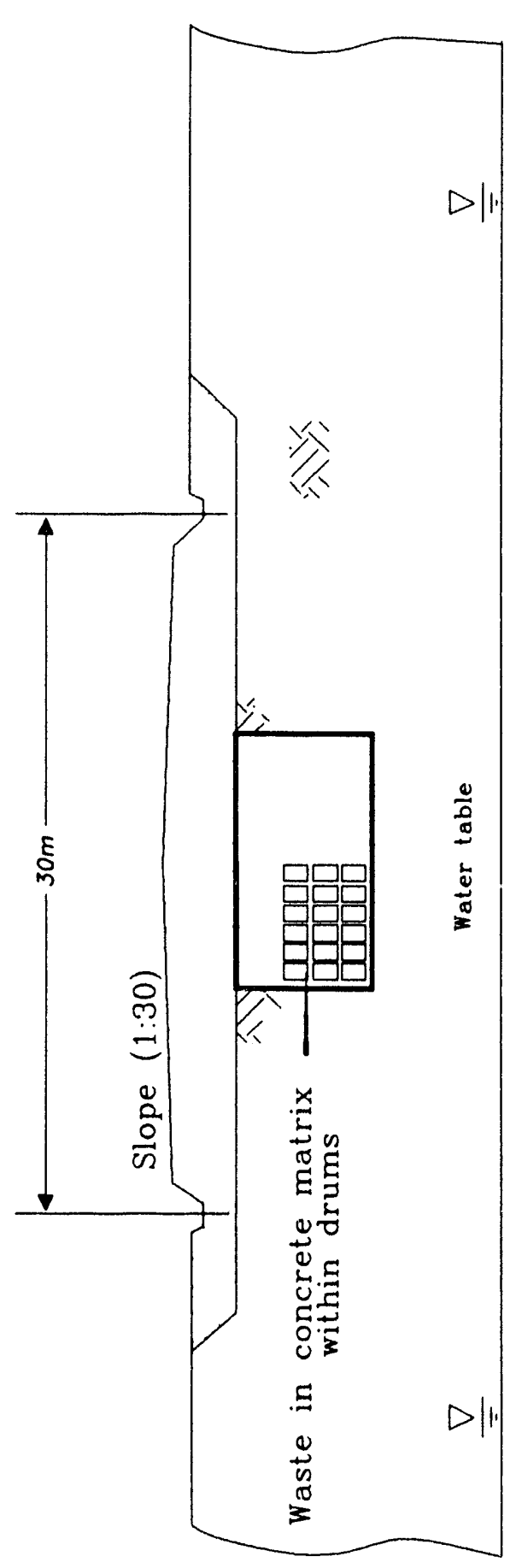

$\stackrel{\infty}{3}$ 
Table 1. Defined parameter values for the earth trench concept (1T)

\begin{tabular}{lc}
\hline Length of trench & $100 \mathrm{~m}$ \\
Width of trench & $10 \mathrm{~m}$ \\
Depth of trench & $5 \mathrm{~m}$ \\
Width of cap & $30 \mathrm{~m}$ \\
Length of cap & $120 \mathrm{~m}$ \\
Thickness of cap & $3 \mathrm{~m}$ \\
Gradient of cap & $1 \mathrm{in} 30$ \\
Porosity of cap & 0.4 \\
Hydraulic conductivity of cap & $10^{-8} \mathrm{~m} / \mathrm{s}$ \\
Distance above water table & $1 \mathrm{~m}$ \\
\hline \hline
\end{tabular}


Table 2. Defined parameter valucs for the engineered vault design (1V)

Internal length of vault

$100 \mathrm{~m}$

Internal width of vault

$10 \mathrm{~m}$

Internal height of vault

$5 \mathrm{~m}$

Thickness: vault base, walls, and roof

$0.3 \mathrm{~m}$

Porosity of concrete

0.25

Hydraulic conductivity of concrete

$10^{-9} \mathrm{~m} / \mathrm{s}$

Ratio of overpack volume to backfill volume

Porosity of backfill

0.4

Hydraulic conductivity of backfill

$10^{-5} \mathrm{~m} / \mathrm{s}$

Width of cap

$30 \mathrm{~m}$

Length of cap

$120 \mathrm{~m}$

Thickness of cap

$3 \mathrm{~m}$

Thickness of rolled clay within cap

$1 \mathrm{~m}$

Gradient of cap, both top surface and clay surface

1 in 30

Porosity of clay, cap fill, and cover material

0.4

Hydraulic conductivity of clay

$10^{-9} \mathrm{~m} / \mathrm{s}$

Hydraulic conductivity of cap fill and cover

$10^{-6} \mathrm{~m} / \mathrm{s}$

material layers

Distance above water table

$1 \mathrm{~m}$ 
Table 3. Nuclides selected and their half-lives

\begin{tabular}{lc}
\hline Nuclide & Half-life \\
\hline${ }^{3} \mathrm{H}$ & $12.35 \mathrm{a}$ \\
${ }^{14} \mathrm{C}$ & $5730 \mathrm{a}$ \\
${ }^{137} \mathrm{Cs}$ & $30.0 \mathrm{a}$ \\
${ }^{230} \mathrm{Th}$ & $7.7 \times 10^{4} \mathrm{a}$ \\
\hline \hline
\end{tabular}

Source: ICRP 1983. 
8

Table 4. Daughter nuclides and their half-lives

\begin{tabular}{lc}
\hline Daughter nuclide & Half-life \\
\hline${ }^{226} \mathrm{Ra}$ & $1600 \mathrm{a}$ \\
${ }^{222} \mathrm{Rn}$ & $3.8235 \mathrm{~d}$ \\
${ }^{218} \mathrm{Po}$ & $3.05 \mathrm{~min}$ \\
${ }^{214} \mathrm{~Pb}$ & $26.8 \mathrm{~min}$ \\
${ }^{214} \mathrm{Bi}$ & $19.9 \mathrm{~min}$ \\
${ }^{214} \mathrm{Po}$ & $1.64 \times 10^{-4} \mathrm{~s}$ \\
${ }^{210} \mathrm{~Pb}$ & $22.3 \mathrm{a}$ \\
${ }^{210} \mathrm{Bi}$ & $5.012 \mathrm{~d}$ \\
${ }^{210} \mathrm{Po}$ & $138.38 \mathrm{~d}$ \\
${ }^{206} \mathrm{~Pb}$ & Stable \\
\hline \hline
\end{tabular}

Source: ICRP 1983. 


\section{WASTEFORM}

For the scenarios of the concept designated 1T, disposal in earth trenches, the waste is in the form of miscellaneous trash materials (paper, plastics, metal, etc.), with principally surface or sorbed contamination. The waste is assumed to have no significant containment. For the scenarios of the concept designated $1 \mathrm{~V}$, disposal in engineered vaults, the waste form is assumed to be a uniformly contaminated concrete matrix within $200-\mathrm{L}$ drums. The defined parameter values for both concepts are given in Table 5. The hydraulic conductivity of the concrete matrix is the same as given in Table 2.

\subsection{GEOSPHERE}

The geosphere is characterized as an unconfined sand aquifer, with the defined properties given in Table 6. The sorption coefficients of relevant elements are provided in Table 7 .

\section{EXPOSURE SCENARIOS}

Two exposure scenarios are defined for Test Case 1: exposure to man via use of a well located $500 \mathrm{~m}$ from the earth trench and engineered vault (Fig. 3) and a building intrusion scenario for the earth trench concept (Fig. 4). Intrusion into the repository is not assumed to occur before $t=100 \mathrm{a}$, due to institutional controls in force up to that time. The house basement excavation is assumed to penetrate into the waste. The remaining features of the intrusion scenario and parameter values were not specified by the IAEA and were to be determined by the individual NSARS research participants. 
Table 5. Density and porosity of waste

\begin{tabular}{lcc}
\hline & Case 1T & Case $1 \mathrm{~V}$ \\
\hline Waste density & $400 \mathrm{~kg} / \mathrm{m}^{3}$ & $2500 \mathrm{~kg} / \mathrm{m}^{3}$ \\
Waste porosity & 0.4 & 0.25 \\
\hline
\end{tabular}


Table 6. Defined properties of the aquifer

\begin{tabular}{lc}
\hline \hline Density & $2000 \mathrm{~kg} / \mathrm{m}^{3}$ \\
Porosity & 0.25 \\
Hydraulic conductivity & $10^{-5} \mathrm{~m} / \mathrm{s}$ \\
Hydraulic gradient & 1 in 100 \\
Saturated thickness & $10 \mathrm{~m}$ \\
Path length & $500 \mathrm{~m}$ \\
Longitudinal dispersivity & $50 \mathrm{~m}$ \\
Transverse dispersivity & $10 \mathrm{~m}$ \\
Water extraction rate & $100 \mathrm{~L} / \mathrm{d}$ \\
Drinking water rate & $2.0 \mathrm{~L} / \mathrm{d}$ \\
\hline \hline
\end{tabular}


Table 7. Sorption coefficients

\begin{tabular}{cc}
\hline Element & $\begin{array}{c}\text { Sorption coefficient, } \\
\mathrm{m}^{3} / \mathrm{kg}\end{array}$ \\
\hline $\mathrm{H}$ & 0 \\
$\mathrm{C}$ & 0 \\
$\mathrm{Cs}$ & 0.3 \\
$\mathrm{Th}$ & 3 \\
$\mathrm{Ra}$ & 0.1 \\
$\mathrm{Po}$ & 0.1 \\
$\mathrm{~Pb}$ & 0.3 \\
\hline \hline
\end{tabular}


ORNL-DWG 93-5752

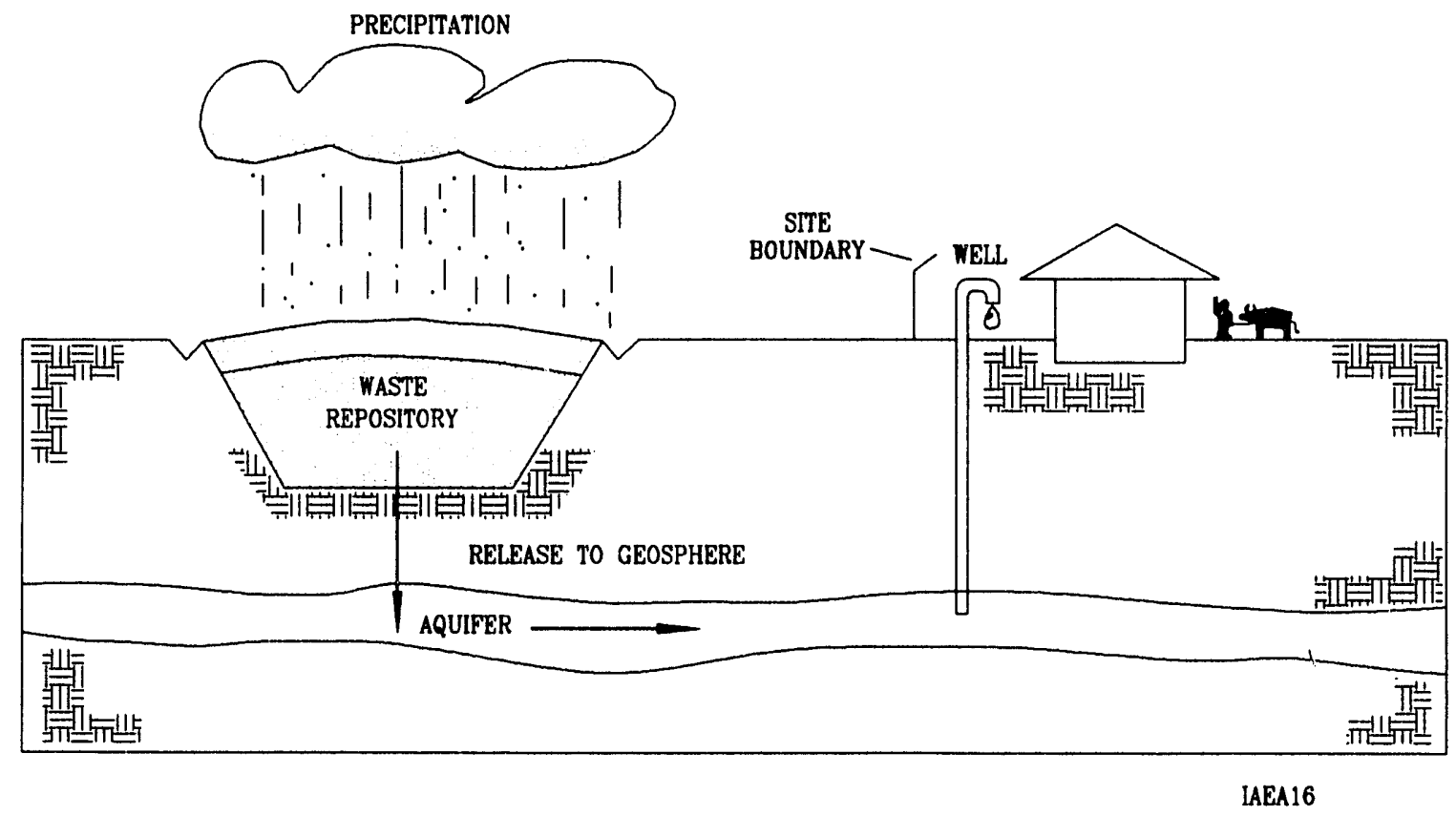

Fig. 3. Schematic of well-water consumption outside the site boundary. 


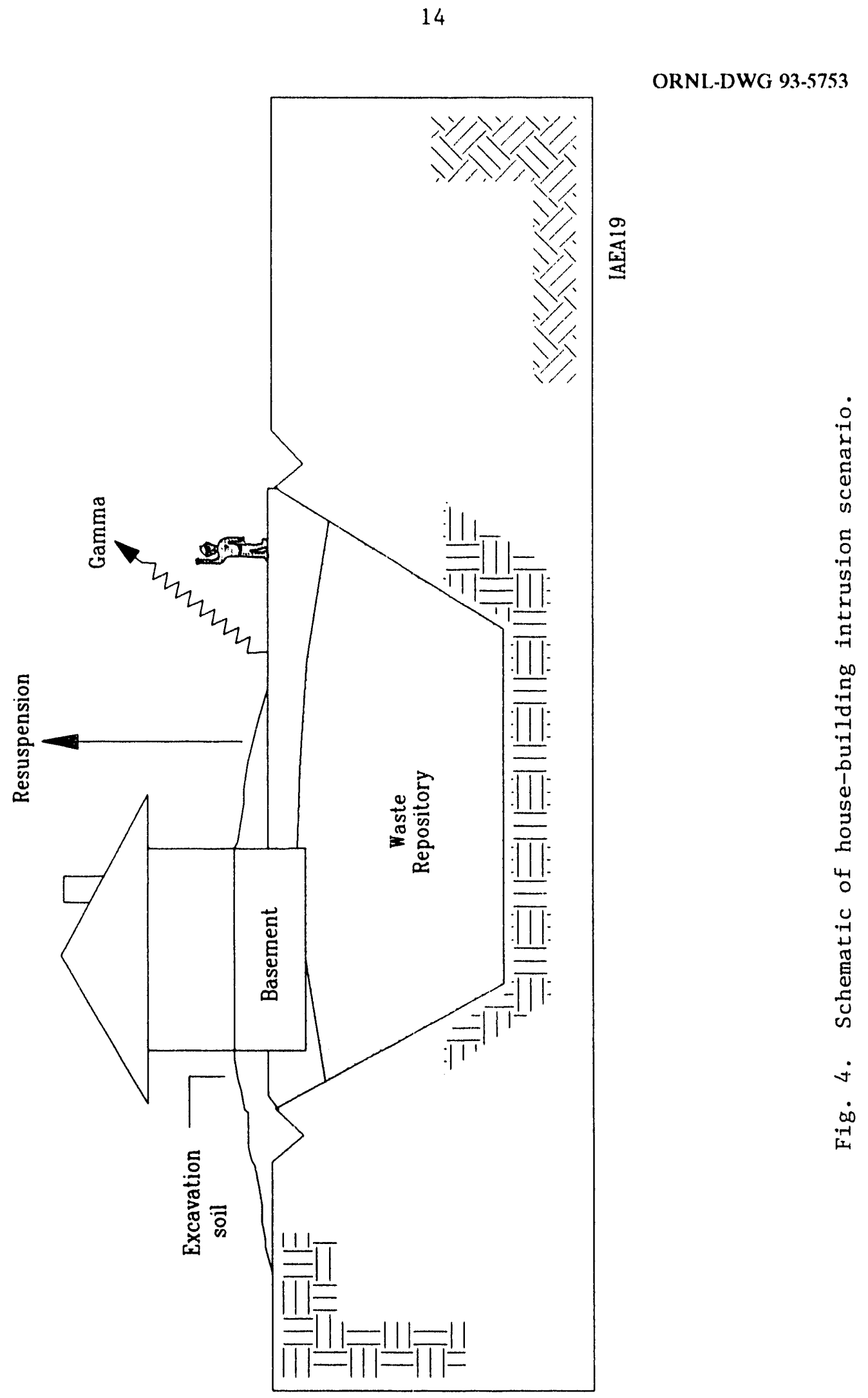




\section{DOSIMETRIC DATA}

The dose conversion factors for all relevant nuclides, including daughter nuclides, are listed separately for inhalation and ingestion in Table 8. For inhalation of ${ }^{22} \mathrm{Rn}$ assumed to be in equilibrium with all daughter nuclides, dose conversion factors of $1.0 \times 10^{-8}$ and $1.4 \times 10^{-8} \mathrm{~Sv} / \mathrm{h}$ per $\mathrm{Bq} / \mathrm{m}^{3}$ are assumed for indoor and outdoor exposure situations respectively (ICRP 1987).

\section{ADDITIONAL PARAMETER VALUES}

For those parameters for which no values were specified, the research participants were requested to provide and use data they believed were the most appropriate to the situation described in the test specifications.

\section{MODELING APPROACH}

This section presents the modeling approach applied to Test Case 1 for the determination of the release rates of nuclides, groundwater transport, and drinking water doses for the earth trench and engineered vault disposal concepts. In addition, the methodology for the determination of the intruder dose from the intruder-construction and intruder-agriculture scenarios is presented.

\subsection{RELEASE RATE TO THE GEOSPHERE}

The release rates from the earth trench and engineered vault concepts were determined by the use of simplified models. The conservative assumption was 
Table 8 Dose conversion factors

\begin{tabular}{l|ll}
\hline \multirow{2}{*}{$\begin{array}{c}\text { Nuclide } \\
\text { (including daughters) }\end{array}$} & \multicolumn{2}{|c}{ Adult dose per unit intake, Sv/Bq } \\
\cline { 2 - 3 } & Inhalation & Ingestion \\
\hline${ }^{3} \mathrm{H}$ & $1.7 \times 10^{-11}$ & $1.7 \times 10^{-11}$ \\
${ }^{14} \mathrm{C}$ & $5.7 \times 10^{-10}$ & $5.7 \times 10^{-10}$ \\
${ }^{137} \mathrm{Cs}$ & $8.7 \times 10^{-9}$ & $1.4 \times 10^{-8}$ \\
${ }^{210} \mathrm{Po}$ & $2.2 \times 10^{-6}$ & $4.4 \times 10^{-7}$ \\
${ }^{210} \mathrm{~Pb}$ & $3.4 \times 10^{-6}$ & $1.4 \times 10^{-7}$ \\
${ }^{226} \mathrm{Ra}$ & $2.1 \times 10^{-6}$ & $3.1 \times 10^{-7}$ \\
${ }^{230} \mathrm{Th}$ & $8.6 \times 10^{-5}$ & $1.5 \times 10^{-7}$ \\
\hline \hline
\end{tabular}

Source: ICRP 1979. 
made that the limiting flux through both systems could be determined by the Darcy flux obtained for the clay caps above the disposal facilities. In both disposal design concepts, the gradient through the caps was assumed to be unity.

The clay cap in the earth trench concept has a hydraulic conductivity of $1 \times 10^{-8} \mathrm{~m} / \mathrm{s}$, which results in a Darcy velocity of $1 \times 10^{-8} \mathrm{~m} / \mathrm{s}$ for a unit gradient. The steady-state pore velocity through the waste was then determined to be $2.5 \times 10^{-8} \mathrm{~m} / \mathrm{s}$ or $0.8 \mathrm{~m} / \mathrm{a}$, determined using a waste porosity of 0.4 .

The clay cap and concrete in the engineered vault concept have hydraulic conductivities of $1 \times 10^{-9} \mathrm{~m} / \mathrm{s}$, resulting in a Darcy velocity of $1 \times 10^{-9} \mathrm{~m} / \mathrm{s}$ for a unit gradient. The steady-state pore velocity through the waste was then determined to be $4 \times 10^{-9} \mathrm{~m} / \mathrm{s}$ or $0.13 \mathrm{~m} / \mathrm{a}$, determined using a waste porosity of 0.25 .

Removal of radionuclides from the waste to the underlying aquifer was determined using a leach rate constant, $K_{l}$. The value of $K_{l}$ was determined according to the formula of Gilbert and others (1989):

$$
K_{l}=\frac{v}{d\left(1+\frac{\rho}{\theta} K_{d}\right)}
$$

where

$v=$ pore velocity through the unsaturated waste, $\mathrm{m} / \mathrm{a}$,

$d=$ depth of the waste, $\mathrm{m}$,

$\rho=$ soil bulk density, $\mathrm{kg} / \mathrm{m}^{3}$,

$\theta=$ soil volumetric water content, $\mathrm{L} / \mathrm{m}^{3}$,

$K_{d}=$ sorption coefficient, $\mathrm{L} / \mathrm{kg}$.

The leach rate constant was used as a factor in the simplified release model based on first order kinetics. Differential equations were written to simulate the system shown in Fig. 5. These coupled differential equations were then solved using a fourth order Runge-Kutta numerical solving routine in the TIME-ZERO computer code (Kirchner 1990). The release rate of each radionuclide was determined from the activity of the radionuclide of interest times the appropriate 


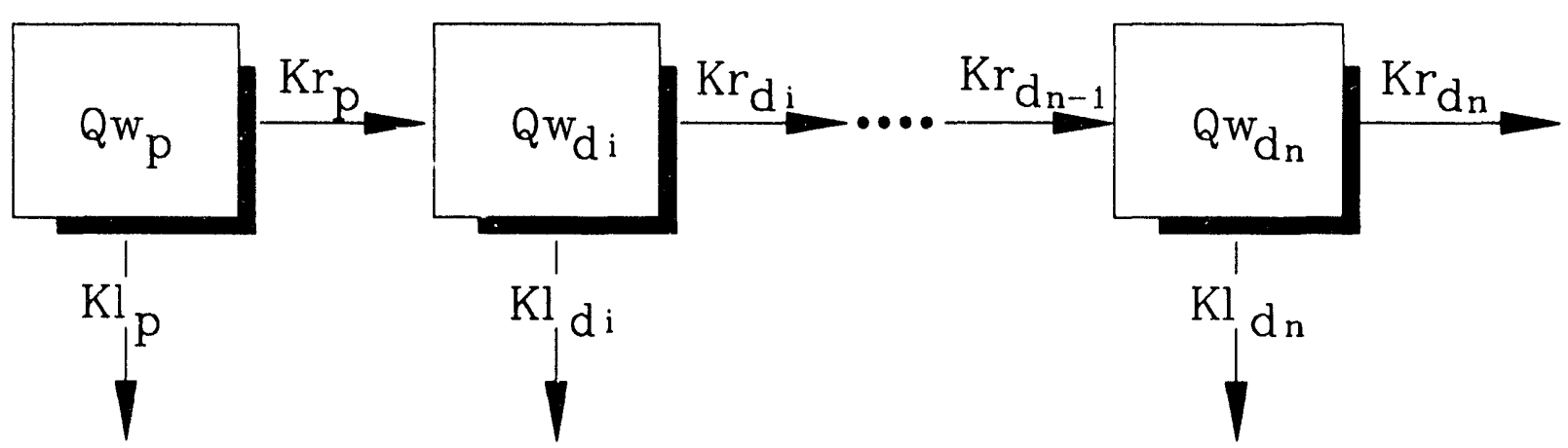

$Q \mathrm{w}_{\mathrm{p}}=$ activity of parent radionuclide in waste, $\mathrm{Bq}$

$\mathrm{Kr}_{\mathrm{p}}=$ decay rate constant of parent radionuclide, $\mathrm{s}^{-1}$

$\mathrm{Kl} \mathrm{p}=$ leach rate constant of parent radionuclide, $\mathrm{s}^{-1}$

$Q w_{d i}=$ activity of the $i^{\text {th }}$ daughter radionuclide in waste, $B q$

$\mathrm{Kr}_{\mathrm{di}}=$ decay rate constant of the $\mathrm{i}^{\text {th }}$ daughter radionuclide, $\bar{s}^{-1}$

$\mathrm{Kl} \mathrm{di}=$ leach rate constant of the $\mathrm{i}^{\text {th }}$ daughter radionuclide, $\mathrm{s}^{-1}$

where $\mathrm{i}=1$ to the number of interest, $n$

Fig. 5. Kinetic release rate model for the earth trench and engineered vault. 
leach rate constant. In each disposal concept, the soil volumetric water content was assumed to be equal to the porosity of the waste; in other words, saturated waste conditions were assumed.

\subsection{GROUNDWATER TRANSPORT}

The equation for contaminant transport in groundwater is

$$
\frac{\partial C}{\partial t}+\frac{1}{R_{d}} \nabla \mu C=\nabla(D \nabla C)-\lambda C
$$

when

$$
C(0, x, y, z)=0
$$

and

$$
\frac{\partial C(t, x, y, z=0, b)}{\partial z}=0
$$

where

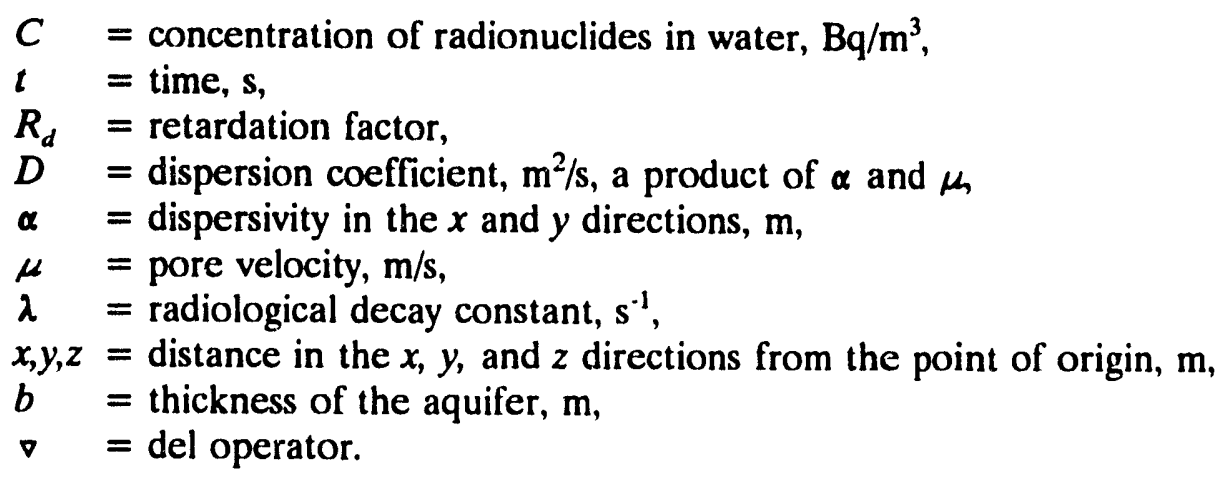

If the source is represented by an area with length $L$ and width $w$ and the contaminant is released instantaneously at $t=0$, then the solution to the above 
equation is

$$
C(t, x, y, z)=\frac{Q_{d}}{n_{e} R_{d}} X(x, t) Y(y, t) Z(z, t)
$$

where

$$
\begin{aligned}
& X(x, t)=\frac{1}{2 L}\left[\operatorname{erf} \frac{x+L / 2-A}{\left(4 D_{x} t / R_{d}\right)^{1 / 2}}-\operatorname{erf} \frac{x-L / 2-A}{\left(4 D_{x} t / R_{d}\right)^{1 / 2}}\right] \exp \left(-\lambda_{d} t\right) \\
& Y(y, t)=\frac{1}{2 w}\left[\operatorname{erf} \frac{w / 2+y}{\left(4 D_{y} t / R_{d}\right)^{1 / 2}}+\operatorname{erf} \frac{w / 2-y}{\left(4 D_{y} t / R_{d}\right)^{1 / 2}}\right]
\end{aligned}
$$

and

$$
Z(z, t)=\frac{1}{b}
$$

where

$C=$ concentration of radionuclides in water, $\mathrm{Bq} / \mathrm{m}^{3}$,

$Q_{c}=$ radionuclide instantaneous release activity, $\mathrm{Bq}$,

$n_{\mathrm{e}}=$ effective porosity,

$R_{d}=$ retardation factor,

$t=$ time after release, $\mathrm{s}$,

$x=$ cartesian coordinate in the $x$ direction,

$y=$ cartesian coordinate in the $y$ direction,

$z=$ cartesian coordinate in the $z$ direction,

$L=$ length of the source, $\mathrm{m}$,

$\mathrm{A}=\mu t / R_{d}$,

$\mu=$ pore velocity, $\mathrm{m} / \mathrm{s}$,

$D_{x}=$ dispersion coefficient in the $x$ direction, $\mathrm{m}^{2} / \mathrm{s}$, a product of $\alpha_{\mathrm{L}}$ and $\mu$

$D_{y}=$ dispersion coefficient in the $y$ direction, $\mathrm{m}^{2} / \mathrm{s}$, a product of $\alpha_{T}$ and $\mu$

$\alpha_{\mathrm{L}}=$ longitudinal dispersivity, $\mathrm{m}$,

$\alpha_{\mathrm{T}}=$ transverse dispersivity, $\mathrm{m}$,

$\lambda_{d}=$ radiological decay constant, $s^{-1}$,

$w=$ width of the source, $m$,

$b \quad=$ thickness of the aquifer, $m$.

erf $=$ error function. 
This solution assumes complete mixing at the point where the concentration is calculated. The solution was modified for a continuous, time-variant release by summing over a series of pulse releases. For a time-variant release, $Q_{\mathrm{d}}$ is a function of time. When the pulse spacing is kept small relative to the standard deviation of the pulse al, the receptor, a continuous, time-variant release can be simulated by

$$
C(t, \because, y, z)=\sum_{i=1}^{k} \frac{Q_{d, i}}{n_{e} R_{d}} X\left(x, t-t_{i}\right) Y\left(y, t-t_{i}\right) Z\left(z, t-t_{i}\right)
$$

where

$$
\begin{aligned}
& Q_{d, i}=\text { activity released during a pulse } i, \mathrm{~Bq}, \\
& t_{i}=\text { time of pulse release, } i, \mathrm{~s},
\end{aligned}
$$

$k=$ the number of pulses.

Release rates were calculated on a yearly basis. The amount of contaminant in each pulse was given by

$$
R * 8
$$

where $R$ is the releasc rate in $\mathrm{Bq} / \mathrm{s}$, and 8 is the incremental time step in seconds. The incremental time step was determired by the dimensionless standard deviation of a pulse given as

$$
\sigma=\left(\frac{2}{P e}+\frac{8}{P_{e}}\right) 0.5
$$

where $P e$ is the peclet number. This number represents the ratio of advection to 
dispersion and is given by

$$
P e=\frac{x}{\alpha}
$$

where $x$ is the longitidinal distance to receptor location and $\alpha$ is longitudinal dispersivity.

The incremental time step 8 was determined by

$$
\delta=\sigma \times G W T
$$

where $G W T$ is groundwater travel time, $(x / \mu) R_{\mathrm{d}}$, in seconds.

The solutions represented by Eqs. 3.1 through 3.5 are modifications to the GRND computer code (Codell 1981) developed by the U.S. Nuclear Regulatory Commission.

\subsection{DETERMINATION OF DRINKING WATER AND INTRUDER DOSES}

Test Case 1 results, i.e., releases to the geosphere, and dose predictions are given in IAEA pro forma format in Sect. 4. The drinking water and intruder exposure scenarios were taken from Kocher and O'Donnell (1987) unless otherwise noted.

\subsubsection{Exposure to Radionuclides in Drinking Water}

Intake of contaminated water by off-site individuals is assumed to result from use of a contaminated groundwater source as drinking water. The annual committed effective dose equivalent, $H$ (Sv/year), from direct ingestion of 
radionuclide $i$ in drinking water $w$ is given by

$$
H_{i w}=C_{i w} U_{w} D_{i}
$$

where

$C_{i w}=$ concentration of radionuclide $i$ in drinking water, $\mathrm{Bq} / \mathrm{L}$,

$U_{w}=$ annual consumption of drinking water, $\mathrm{L} / \mathrm{a}$,

$D_{i}=$ dose conversion factor for ingestion of radionuclide $i, \mathrm{~Sv} / \mathrm{Bq}$.

In implementing the model, a daily consumption of contaminated drinking water of $2 \mathrm{~L}$, or an annual consumption of $730 \mathrm{~L}$, is assumed.

\subsection{EXPOSURE PATHWAYS FOR DIRECT INTRUSION INTO DISPOSAL UNITS}

Exposures resulting from direct intrusion into the earth trench are assumed to occur according to the intruder-construction and intruder-agriculture scenarios. In these scenarios, all waste in the disposal unit is assumed to be easily accessible during normal excavation activities and to be indistinguishable from native soil.

\subsubsection{Exposure Scenarios and Exposure Pathways for Inadvertent Intruders}

In estimating doses to an intruder following loss of active institutional control over the disposal facility, the intruder is assumed to establish a permanent homestead on the site 100 years after disposal. Furthermore, the intruder is assumed to have no a priori knowledge of waste disposal activities at the facility.

Exposures of an intruder while constructing a foundation for a home that extends into the disposal unit is considered under the intruder-construction scenario. During construction, doses are received from inhalation of suspended radionuclides and from external exposure. 
In the intruder-agriculture scenario, an intruder is assumed to construct a home directly on top of the disposal unit, and the foundation is assumed to extend into the disposal unit. Radioactive wastes are assumed to be exhumed during construction of the foundation, and all waste remaining in the disposal unit at the time direct intrusion occurs is assumed to be indistinguishable from native soil. Some of the exhumed waste is assumed to be mixed with native soil in the intruders's vegetable garden, and the following pathways involving exposure to radionuclides in the solid waste are assumed to occur:

- ingestion of vegetables grown in the contaminated soil,

- direct ingestion of contaminated soil from the garden in conjunction with vegetable intakes,

- external exposure to contaminated soil while working in the garden or residing in the home on top of the disposal units, and

- inhalation of radionuclides suspended in the air from contaminated soil while working in the garden or residing in the home.

\subsubsection{Dase Conversion Factors for Internal and External Exposure}

From the descriptions of the assumed exposure scenarios given above, doses to off-site individuals and inadvertent intruders are assumed to result from ingestion and inhalation of radionuclides and from external exposure to photons emitted by radionuclides in contaminated soil or in the disposal unit. This section presents the factors that are used in the dose analysis to convert intakes of radionuclides via ingestion and inhalation to internal doses and to convert concentrations of radionuclides in water, soil, or the disposal unit to external dose rates.

The internal dose conversion factors for ingestion and inhalation of radionuclides were given by the IAEA and are shown in Table 8 . These internal dose conversion factors are those presently recommended by the International Commission on Radiological Protection (ICRP 1979). 
The dose conversion factors for external exposure give external dose rates per unit concentration of radionuclides. These factors depend on the distribution of radionuclides in the source region, the amount of self-shielding provided by the source region, and the amount of shielding between the source region and the location of the exposed individual. Therefore, dose conversion factors for external exposure are required for two separate sets of circumstances: 1) the assumed exposure pathways involving exposure to activity in contaminated soil while gardening or during indoor residence and 2 ) the exposure to activity in the disposal unit during excavation at the site.

For external exposure to radionuclides in contaminated soil while gardening or during indoor residence and for external exposure to radionuclides in the disposal unit during excavation into the unit, the source region is assumed to be a uniformly contaminated slab of infinite lateral extent. Depending upon the exposure scenario, the slab is assumed to have either finite or infinite thickness, and the shielding provided by uncontaminated material between the source and receptor locations is taken into account. The idealized distributions of radionuclides in the source region assumed in the dose analysis probably are reasonable because about $1 \mathrm{~m}$ of soil-equivalent material between a source and a receptor location provides essentially complete shielding (Kocher and Sjoreen 1985).

In all calculations of external dose while working in the vegetable garden or residing in a house on top of disposal units, an exposed individual is assumed to be $1 \mathrm{~m}$ from the source region (U.S.DOE 1988). In all cases, the shielding provided by $1 \mathrm{~m}$ of air is negligible compared with the shielding provided by the soil in the source region itself.

For external exposures while working in the vegetable garden, the source region is assumed to be a slab extending from the ground surface to a depth of $15 \mathrm{~cm}$, which is a typical thickness of a plowed layer. The external dose-rate conversion factors for this case are given in Table 9. For external exposure while residing in the house and for the intruder-construction scenario, the source region is assumed to be a slab of essentially infinite thickness beginning at the ground 
Table 9. External dose-rate conversion factors for radionuclides uniformly distributed in $15 \mathrm{~cm}$ of surface soil and uniformly distributed in infinite thickness of soil

\begin{tabular}{|c|c|c|}
\hline \multirow{2}{*}{ Nuclide } & \multicolumn{2}{|c|}{ Dose-rate factor, Sv/year per $\mathrm{Bq} / \mathrm{m}^{3}$} \\
\hline & $15-\mathrm{cm}$ soil thickness & infinite soil thickness \\
\hline${ }^{137} \mathrm{Cs}$ & $6.5 \times 10^{-10}$ & $7.8 \times 10^{-10}$ \\
\hline${ }^{214} \mathrm{~Pb}$ & $2.6 \times 10^{-10}$ & $3.0 \times 10^{-10}$ \\
\hline${ }^{214} \mathrm{Bi}$ & $1.6 \times 10^{.9}$ & $2.1 \times 10^{-9}$ \\
\hline
\end{tabular}


surface, with no shielding assumed between the source region and the receptor location other than that provided by the soil in the source region (shielding provided by the walls of the house during indoor residence is taken into account in the dose analysis itself). The external dose-rate conversion factors for this case are also given in Table 9.

The external dose-rate conversion factors in Table 9 were obtained from: 1) calculations of absorbed dose rates in air for monoenergetic photon sources in soil (Kocher and Sjoreen 1985), 2) the spectrum of photons emitted by each radionuclide (Kocher 1981), and 3) the branching fractions in radioactive decay chains (Kocher 1981). For all radionuclides, absorbed dose in air is converted to effective dose equivalent in an exposed individual by multiplying by a factor of 0.8 . This is an excellent approximation for all photon energies above $0.1 \mathrm{MeV}$ and provides a conservative overestimate of dose equivalent for lower photon energies.

\subsubsection{Models and Parameter Values for Intruder Exposure Pathways}

This section presents the models used to calculate doses to off-site individuals and inadvertent intruders for the various exposure pathways involving direct intrusion into disposal units. The parameter values assumed in implementing the models are presented.

\subsubsection{Intruder Scenario Exposure Calculations}

Exposures of intruders according to the intruder-construction scenario are assumed to result when an intruder constructs a house basement in the waste disposal unit. Exposures occur according to the inhalation and external exposure scenarios presented below. The exposure time period is assumed to occur for $500 \mathrm{~h} /$ year. 
Exposures of intruders according to the intruder-agriculture scenario are assumed to result when an intruder exhumes waste from disposal units while digging a foundation for a home on top of the units themselves and mixing some of the waste with native soil in a vegetable garden. The exposure pathways assumed for this scenario include: 1) ingestion of vegetables grown in contaminated soil, 2) direct ingestion of contaminated soil in conjunction with ingestion of vegetables, 3) external exposure to contaminated soil while working in the garden and during indoor residence, and 4 ) inhalation of suspended radioactive particles while working in the garden and during indoor residence. The equations for these exposure scenarios are presented below.

The annual committed effective dose equivalent (Sv/year) from ingestion of radionuclide $i$ in vegetables $v$ is given by

$$
H_{i v}=C_{i v} U_{1} D_{i}
$$

where

$C_{i v}=$ concentration of radionuclide $i$ in vegetables, $\mathrm{Bq} / \mathrm{kg}$,

$U_{v}=$ annual consumption of vegetables, $\mathrm{kg} /$ year,

$D_{i}=$ dose conversion factor for ingestion of radionuclide $i, \mathrm{~Sv} / \mathrm{Bq}$.

Radionuclides are transferred to vegetables via root uptake from the contaminated soil. Radionuclide concentrations in vegetables are given by

$$
\begin{aligned}
C_{i v} & =B_{i v} C_{i s} / p_{s} \\
& =B_{i v} f_{i s} C_{i v} / p_{s}
\end{aligned}
$$

where

$B_{i v}=$ plant-to-soil concentration ratio for radionuclide $i(\mathrm{~Bq} / \mathrm{kg}$ wet weight in vegetation per $\mathrm{Bq} / \mathrm{kg}$ dry weight in soil), 
$C_{i s}=$ concentration of radionuclide $i$ in soil in vegetable garden, $\mathrm{Bq} / \mathrm{m}^{3}$,

$p_{s}=$ density of soil, $\mathrm{kg} / \mathrm{m}^{3}$,

$C_{i t}=$ concentration of radionuclide $i$ in disposal units, $\mathrm{Bq} / \mathrm{m}^{3}$,

$f_{i s}=$ dilution factor for mixing of radionuclide $i$ from disposal units into soil in vegetable garden.

The plant-to-soil concentration ratios in vegetables assumed in implementing the model are given in Table 10. The other parameter values assumed in the model are: 1) a dilution factor for mixing of radionuclides from the disposal units into native soil in the vegetable garden of 0.2 (Napier et al. 1984), 2) a soil density of $1,400 \mathrm{~kg} / \mathrm{m}^{3}$ (Baes and Sharp 1983), and 3) an annual consumption of contaminated vegetables by an individual of $90 \mathrm{~kg}$ (U.S.NRC 1977). Ingestion of contaminated soil is assumed to occur as a result of incomplete washing of vegetables before consumption.

The annual committed effective dose equivalent (Sv/year) from direct ingestion of radionuclide $i$ in contaminated soil $s$ is given by

$$
H_{i s}=C^{m}{ }_{i s} U_{s} D_{i}
$$

where

$C^{m}{ }_{i s}=$ mass concentration of radionuclide $i$ in soil in vegetable garden, $\mathrm{Bq} / \mathrm{kg}$,

$U_{s}$ = annual consumption of contaminated soil, $\mathrm{kg} / \mathrm{year}$,

$D_{i}=$ dose conversion factor for ingestion of radionuclide $i, \mathrm{~Sv} / \mathrm{Bq}$.

Radionuclide concentration in soil, by mass, in the vegetable garden is given by

$$
C^{n}{ }_{i s}=f_{i s} C_{i} / p_{s}
$$


Table 10. Elemental plant-to-soil concentration ratios in vegetables

\begin{tabular}{|c|c|l||}
\hline Element & \multicolumn{1}{|c|}{ B $_{\text {iv }}$} & \multicolumn{1}{|c|}{ Source } \\
\hline $\mathrm{H}$ & 4.8 & $\begin{array}{l}\text { Reg. Guide 1.109 } \\
\text { (U.S.NRC 1977) }\end{array}$ \\
\hline $\mathrm{C}$ & $5.5 \times 10^{-2}$ & $\begin{array}{l}\text { 1\% of Reg. Guide 1.109 } \\
\text { (U.S.NRC 19/7) }\end{array}$ \\
\hline $\mathrm{Cs}$ & $9.5 \times 10^{-3}$ & Ng 1982 \\
\hline $\mathrm{Th}$ & $5.0 \times 10^{-4}$ & Peterson 1983 \\
\hline $\mathrm{Ra}$ & $2.6 \times 10^{-2}$ & Peterson 1983 \\
\hline $\mathrm{Pb}$ & $1.0 \times 10^{-2}$ & Ng 1982 \\
\hline $\mathrm{Po}$ & $2.4 \times 10^{-4}$ & Peterson 1983 \\
\hline
\end{tabular}

$\mathrm{B}_{\mathrm{iv}}=$ plant-to-soil concentration ratio for radionuclide $i(\mathrm{~Bq} / \mathrm{kg}$ wet weight in vegetation per $\mathrm{Bq} / \mathrm{kg}$ dry weight in soil). 
where

$$
\begin{aligned}
C_{i t}= & \text { concentration of radionuclide } i \text { in disposal units, } \mathrm{Bq} / \mathrm{m}^{3}, \\
f_{i s}= & \text { dilution factor for mixing radionuclide } i \text { from disposal units into soil in } \\
& \text { vegetable garden, } \\
p_{s}= & \text { density of soil, } \mathrm{kg} / \mathrm{m}^{3} .
\end{aligned}
$$

In implementing the model, a dilution factor for mixing of radionuclides from the disposal units into native soil in the vegetable garden of 0.2 and a soil density of $1,400 \mathrm{~kg} / \mathrm{m}^{3}$ are assumed, as in the model for the vegetable pathway. A daily consumption of contaminated soil from the vegetable garden of $0.1 \mathrm{~g}$, i.e., an annual consumption of $0.037 \mathrm{~kg}$, is also assumed (U.S.DOE 1986).

For external exposure $e$ to contaminated soil while working in the vegetable garden, the annual effective dose equivalent (Sv/year) from radionuclide $i$ is given by

$$
H_{i e}=C_{i s} U D_{i s}
$$

where

$C_{i s}=$ concentration of radionuclide $i$ in soil in vegetable garden, $\mathrm{Bq} / \mathrm{m}^{3}$,

$U_{s}=$ fraction of the year during which external exposure to contaminated soil in vegetable garden occurs,

$D_{i s}=$ dose conversion factor for external exposure to radionuclide $i$ in soil, Sv/year per $\mathrm{Bq} / \mathrm{m}^{3}$.

As in models for the vegetable and soil ingestion pathways, the radionuclide concentrations, by volume, in soil in the vegetable garden are given by

$$
C_{i s}=f_{i s} C_{i t}
$$


where

$C_{i t}=$ concentration of radionuclide $i$ in disposal units, $\mathrm{Bq} / \mathrm{m}^{3}$,

$f_{i s}=$ dilution factor for mixing of radionuclide $i$ from disposal units into soil in vegetable garden.

In implementing the model, a dilution factor for mixing of radionuclides from the disposal units into native soil in the vegetable garden of 0.2 is assumed, as in the models for the vegetable and soil ingestion pathways. Also assumed is a fraction of the year of 0.01 during which external exposure while working in the garden occurs, i.e., an exposure time of about $100 \mathrm{~h} /$ year (Oztunali et al. 1981).

For external exposure to waste during indoor residence on top of the disposal units, the annual effective dose equivalent (Sv/year) from radionuclide $i$ is given by

$$
H_{i e}=C_{i t} U_{i} D_{i} S_{i}
$$

where

$C_{i t}=$ concentration of radionuclide $i$ in disposal units, $\mathrm{Bq} / \mathrm{m}^{3}$,

$U_{t}=$ fraction of the year during which external exposure to waste in disposal units during indoor residence occurs,

$D_{i t}=$ dose conversion factor for external exposure to radionuclide $i$ in disposal units, Sv/year per $\mathrm{Bq} / \mathrm{m}^{3}$,

$S_{i}=$ shielding factor for radionuclide $i$ during indoor residence.

The shielding factor takes into account the reduction in external dose provided by the walls and floor of the house. In implementing the model, a fraction of the year during which exposure in the house occurs of 0.5 , i.e., an exposure time of $4,380 \mathrm{~h} /$ year, is assumed (Oztunali et al. 1981). A shielding factor from indoor residence of 0.7 is assumed for all radionuclides (U.S.NRC 1977). 
While working in the contaminated vegetable garden or residing in a house on top the disposal units, the annual committed effective dose equivalent (Sv/year) from inhalation of radionuclide $i$ in air $a$ is given by

$$
H_{i a}=C_{i a} f_{a} U_{a} D_{i}
$$

where

$C_{i a}=$ concentration of radionuclide $i$ in air, $\mathrm{Bq} / \mathrm{m}^{3}$,

$f_{a}=$ fraction of the year during which inhalation occurs,

$U_{a}=$ air intake, $\mathrm{m}^{3} /$ year,

$D_{i}=$ dose conversion factor for inhalation of radionuclide $i, \mathrm{~Sv} / \mathrm{Bq}$.

Estimates of concentrations of suspended activity in air are obtained using a mass-loading model, which is based on observations of airborne concentrations of naturally occurring materials, such as uranium and thorium, relative to their concentrations in surface soils (Anspaugh et al. 1975). In this model, airborne concentrations of radionuclides are given by

$$
C_{i a}=C_{i s} L_{d} p_{s}
$$

where

$C_{i s}=$ concentration, by volume, of radionuclide $i$ in soil, $\mathrm{Bq} / \mathrm{m}^{3}$,

$L_{a}=$ mass loading of soil in the atmosphere, $\mathrm{kg} / \mathrm{m}^{3}$,

$p_{s}=$ density of soil, $\mathrm{kg} / \mathrm{m}^{3}$.

For inhalation exposures while working in the vegetable garden, the concentration, by volume, of radionuclide $i$ in soil is given by

$$
C_{i s}=f_{i s} C_{i t}
$$


where

$$
\begin{aligned}
C_{i t}= & \text { concentration of radionuclide } i \text { in disposal units, } \mathrm{Bq} / \mathrm{m}^{3}, \\
f_{i s}= & \text { dilution factor for mixing of radionuclide } i \text { from disposal units into soil } \\
& \text { in vegetable garden. }
\end{aligned}
$$

In implementing the model, several parameter values are again assumed, as in the model for external exposure while working in the garden: 1) a dilution factor, 0.2 , for mixing of radionuclides from the disposal units into native soil in the garden, 2) a soil density of $1,400 \mathrm{~kg} / \mathrm{m}^{3}$, and 3) a fraction of the year, 0.01 (about $100 \mathrm{~h} /$ year), during which exposure while working in the garden occurs. An annual air intake of $8,000 \mathrm{~m}^{3}$ is also assumed (U.S.NRC $197^{\circ} i$ ). Finally, an atmospheric mass loading of soil of $10^{-6} \mathrm{~kg} / \mathrm{m}^{3}$ is assumed, which is ten times greater than the average background value (Anspaugh et al. 1975) and takes into account increased particle suspension (dust) during gardening activities.

For inhalation exposures while residing in the house, the airborne concentration of radionuclide $i$ is given by

$$
C_{\text {ia }}=S_{i} C_{i n} L_{d} d p s
$$

where

$S_{i}=$ ratio of indoor to outdoor air concentration for radionuclide $i$,

$C_{i t}=$ concentration of radionuclide $i$ in disposal units, $\mathrm{Bq} / \mathrm{m}^{3}$,

$L_{\mathrm{a}}=$ mass loading of soil in the atmosphere, $\mathrm{kg} / \mathrm{m}^{3}$,

$p_{s}=$ density of soil, $\mathrm{kg} / \mathrm{m}^{3}$.

In implementing the model, a soil density of $1,400 \mathrm{~kg} / \mathrm{m}^{3}$, a fraction of the year during which exposure in the house occurs of $0.5(4,380 \mathrm{~h} / \mathrm{year})$, and an annual air intake of $8,000 \mathrm{~m}^{3}$ are again assumed. An atmospheric mass loading of 
soil of $10^{-7} \mathrm{~kg} / \mathrm{m}^{3}$ is assumed, which is the average background value (Anspaugh et al. 1975). Finally, a ratio of indoor to outdoor air concentration of 0.24 is assumed, except no reduction in indoor concentrations is assumed to occur for ${ }^{3} \mathrm{H}$ and ${ }^{14} \mathrm{C}$ (Kocher 1980). The reduction in indoor air concentrations results primarily from deposition of airborne particles onto indoor surfaces.

\subsubsection{Rn-222 Inhalation Dose}

The dose from inhalation of radon and radon daughters in a structure built over the: waste was calculated from (Rogers and Hung 1987):

$$
D=\frac{Q}{H \lambda_{r} V F} E \sqrt{\lambda D_{w}} \tanh \left(100 b_{w} T_{w}\right) \exp \left(-100 b_{1} T_{1}-b_{2} T_{2}\right) D_{i} U_{\propto c}
$$

where

$Q={ }^{226} \mathrm{Ra}$ activity in waste, $\mathrm{Bq}$,

$E={ }^{22} \mathrm{Rn}$ emanation fraction,

$H=$ height of rooms in structure, $\mathrm{cm}$,

$\lambda_{r}=$ air ventilation rate of structure, air exchanges per second,

$\lambda=$ decay rate constant of ${ }^{22} \mathrm{Rn}, \mathrm{s}^{-1}$,

$V \quad=$ volume of waste, $\mathrm{m}^{3}$,

$T_{1}=$ thickness of earthen cover, $\mathrm{m}$,

$T_{2}=$ thickness of concrete floor in house, $\mathrm{cm}$,

$D_{w}=$ radon diffusion coefficient of waste, $\mathrm{cm}^{2} / \mathrm{s}$,

$D_{1}=$ radon diffusion coefficient of cover, $\mathrm{cm}^{2} / \mathrm{s}$,

$D_{2}=$ radon diffusion coefficient of concrete, $\mathrm{cin}^{2} / \mathrm{s}$,

$T_{w}=$ thickness of waste, $\mathrm{m}$,

$D_{i}={ }^{m} \mathrm{Rn}$ dose conversion factor for inhalation, $\mathrm{Sv} / \mathrm{h}$ per $\mathrm{Bq} / \mathrm{m}^{3}$,

$U_{o c}=$ Occupancy time in the house, $\mathrm{h}$,

$a_{i}=P_{i} 2 D_{i}, i=w, 1,2$,

$b_{i}=\sqrt{\lambda / D_{i}} \quad(i=w, 1,2)$,

$p_{i}=$ porosity $(i=\mathrm{w}, 1,2)$, 


$$
\begin{aligned}
m_{i}= & 0.01 \mathrm{Md} / P_{i}(i=\mathrm{w}, 1,2) \\
M= & \text { moisture content, dry weight percent, } \\
k= & 0.26 \mathrm{~Bq} / \mathrm{m}^{3} \text { of }{ }^{222} \mathrm{Rn} \text { in water per } \mathrm{Bq} / \mathrm{m}^{3} \text { in air, } \\
d_{i}= & \text { density }(i=w, 1,2), \\
F= & \frac{1}{2}\left[1+\sqrt{a_{w} / a_{c}} \tanh \left(100 b_{w} T_{w}\right]+\frac{1}{2}\left[1-\sqrt{a_{w} / a_{c}} \tanh \right.\right. \\
& \left.\left(100 b_{w} T_{w}\right)\right] \exp \left(-2\left(100 b_{1} T_{1}+b_{2} T_{2}\right)\right) .
\end{aligned}
$$

In implementing the model, an emanation fraction of 0.3 was assumed.

The height of the room was assumed to be $2.4 \mathrm{~m}$ with an air ventilation rate of $1.4 \times 10^{-4} \mathrm{sec}^{-1}$. The cover was assumed to be removed, while the concrete thickness was assumed to be $15 \mathrm{~cm}$. The radon diffusion coefficients were assumed to be $1 \times 10^{-2} \mathrm{~cm}^{2} / \mathrm{s}$ for the waste (Rogers et al. 1984) and $3 \times 10^{-2} \mathrm{~cm}^{2} / \mathrm{s}$ for the concrete (Culot et al. 1976). The dose conversion factor for ${ }^{22} \mathrm{Rn}$ was given by the IAEA as $1.0 \times 10^{-8} \mathrm{~Sv} / \mathrm{h}$ per $\mathrm{Bq} / \mathrm{m}^{3}$ for indoor exposures. An occupancy time of $4380 \mathrm{~h}$ was assumed, which is the time for indoor residence assumed in the intruder-agriculture scenario. The dose from radon due to outdoor exposures was not considered; instead, the radon daughters were assumed to remain in the soil, and the dose was received from external exposure.

\section{RESULTS}

In order to allow comparisons of Test Case 1 results between the research participants, the IAEA provided a series of pro forma formats. The results of Test Case 1 are provided in Exhibits 1 through 6 using the IAEA pro forma formats. The following comments on the results of Test Case 1 are given with reference to the information provided on the IAEA pro forma sheets.

The release rates for both disposal concepts are directly proportional to the pore velocity assumed in the unsaturated zone. The release rates for ${ }^{226} \mathrm{Ra}$ and ${ }^{210} \mathrm{~Pb}$ are shown to be higher than that for ${ }^{230} \mathrm{Th}$ since the release rate was determined from the leach rate constant. The leach rate constants for ${ }^{226} \mathrm{Ra}$ and ${ }^{210} \mathrm{~Pb}$ 
COUNTRY: USA

ORGANIZATION: ORNL/DOE

PAGE 1 OF 10

DATE $1992-11-30$

\section{RESULTS FOR NSARS TEST CASE 1T: EARTH TRENCH}

\section{TR. RELEASE TO GEOSPHERE}

\section{Description of release model}

For all nuclides, leach rate was determined from:

$$
\frac{v}{d\left(1+\frac{p}{\theta} k d\right)}
$$

Release rate was equal to the product of the trench activity as a function of time and the leach rate constant. Pore velocity (v) was assumed equal to cap Darcy velocity $(0.32 \mathrm{~m} / \mathrm{a})$ divided by the porosity of the waste $(0.4)$. Pore velocity was determined to be $0.8 \mathrm{~m} / \mathrm{a}$.

\section{Parameter values (additional to those specified)}

Infiltration in the cap was assumed equal to the hydraulic conductivity times the gradient $\left(3.2 \times 10^{-1} \mathrm{~m} / \mathrm{a}\right)$.

The distribution coefficient, $\mathrm{kd}$, for waste was assumed to be equal to that reported for soil.

Ra-226 and ${ }^{210} \mathrm{~Pb}$ were released at their own rates according to their respective leach rate constants.

Leachate flowrate: $\underline{320 \mathrm{~m}^{3} / \mathrm{a}}$

Table 1TR. Maximum release rate

\begin{tabular}{ccc}
\hline $\begin{array}{c}\text { Nuclide } \\
\text { (incl. daughters) }\end{array}$ & $\begin{array}{c}\text { Maximum release } \\
\text { rate, Bg/a }\end{array}$ & $\begin{array}{c}\text { Time of } \\
\text { maximum, a }\end{array}$ \\
\hline${ }^{3} \mathrm{H}$ & $1.6 \times 10^{11}$ & 1 \\
${ }^{14} \mathrm{C}$ & $1.6 \times 10^{11}$ & 1 \\
${ }^{137} \mathrm{Cs}$ & $5.3 \times 10^{8}$ & 1 \\
${ }^{200} \mathrm{Th}$ & $5.3 \times 10^{7}$ & 1 \\
${ }^{20} \mathrm{Ra}$ & $2.8 \times 10^{8}$ & 1000 \\
${ }^{210} \mathrm{~Pb}$ & $9.2 \times 10^{7}$ & 1000 \\
\hline
\end{tabular}

Exhibit 1. Results for NSARS Test Case 1T, Earth Trench: 1TR Release to Geosphere. 
RESULTS FOR NSARS TEST CASE 1T: EARTH TRENCH

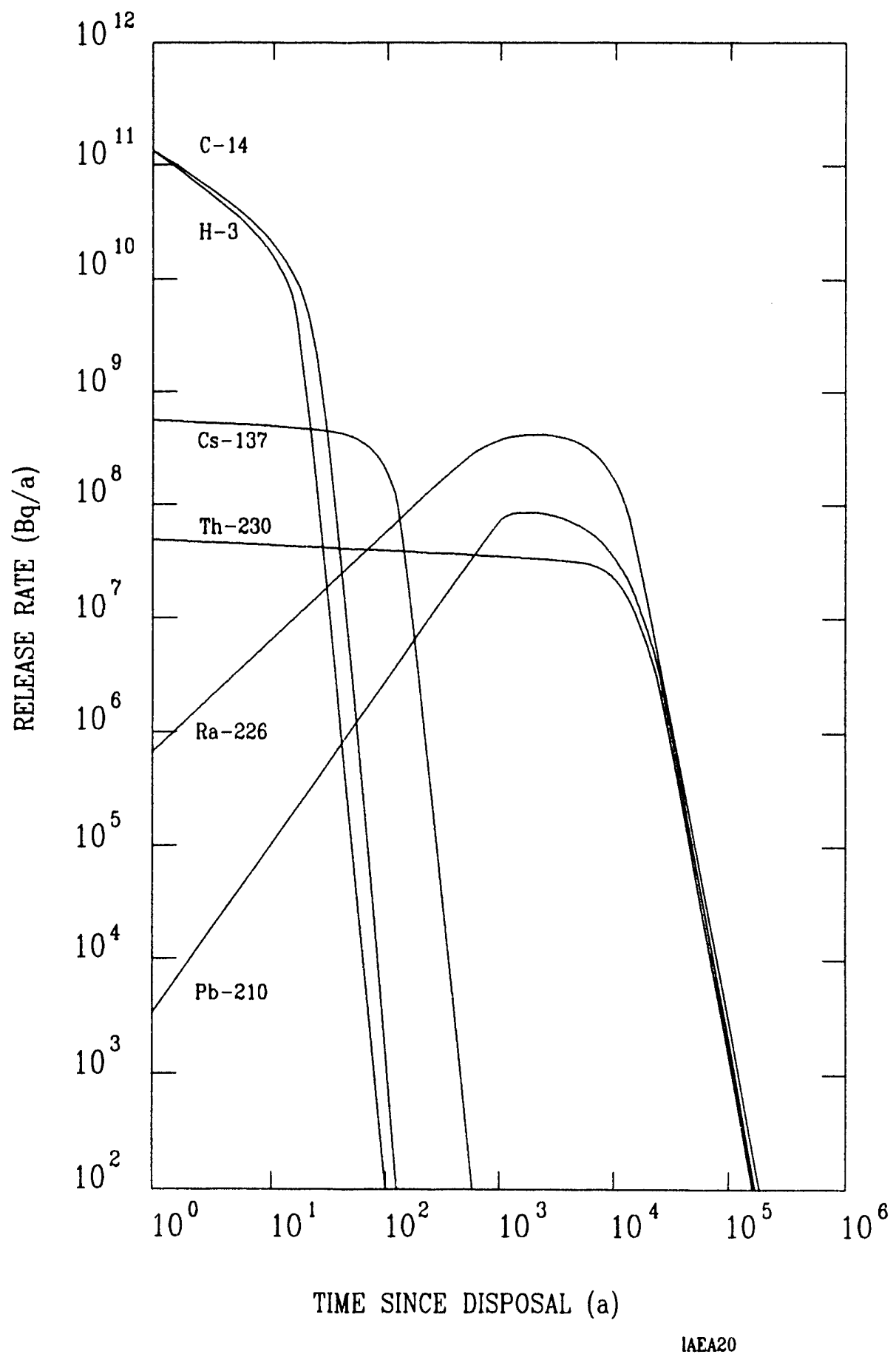

Exhibit 1. (continued). 
COUNTRY:

USA

PAGE $\quad 3 \quad$ OF 10

ORGANIZATION:

ORNL/DOE

DATE $1992-11-30$

\section{RESULTS FOR NSARS TEST CASE 1T: EARTH TRENCH}

1TW. EXPOSURE TO MAN VIA WELL USE

Description of transport model

Codell analytical model (GRND) for a constant velocity, isotropic, homogeneous aquifer of constant thickness was used.

Parameter values (additional to those specified)

Aquifer thickness is $10 \mathrm{~m}$; it was assumed that the contaminant was vertically mixed to this depth.

Table 1TW. Effective dose equivalent for drinking well water

\begin{tabular}{ccc}
\hline $\begin{array}{c}\text { Nuclide } \\
\text { (incl. daughters) }\end{array}$ & $\begin{array}{c}\text { Maximum dose, } \\
\text { Sv/a }\end{array}$ & $\begin{array}{c}\text { Time of } \\
\text { maximum, a }\end{array}$ \\
\hline${ }^{3} \mathrm{H}$ & $1.6 \times 10^{-5}$ & 40 \\
${ }^{14} \mathrm{C}$ & $3.2 \times 10^{-3}$ & 40 \\
${ }^{137} \mathrm{Cs}$ & $\cdots$ & $\cdots$ \\
${ }^{230} \mathrm{Th}$ & $9.0 \times 10^{-8}$ & $4.4 \times 10^{5}$ \\
${ }^{226} \mathrm{Ra}$ & $5.6 \times 10^{-6}$ & $4.4 \times 10^{5}$ \\
${ }^{210} \mathrm{~Pb}$ & $8.4 \times 10^{-7}$ & $4.4 \times 10^{5}$ \\
${ }^{210} \mathrm{Po}$ & $8.0 \times 10^{-6}$ & $4.4 \times 10^{5}$ \\
\hline
\end{tabular}

Exhibit 2. Results for NSARS Test Case 1T, Earth Trench: 1TW Exposure to Man via Well Use. 
COUNTRY:

ORGANIZATION: ORNL/DOE
PAGE $\frac{4}{1992-11-30}$

RESULTS FOR NSARS TEST CASE 1T: EARTH TRENCH

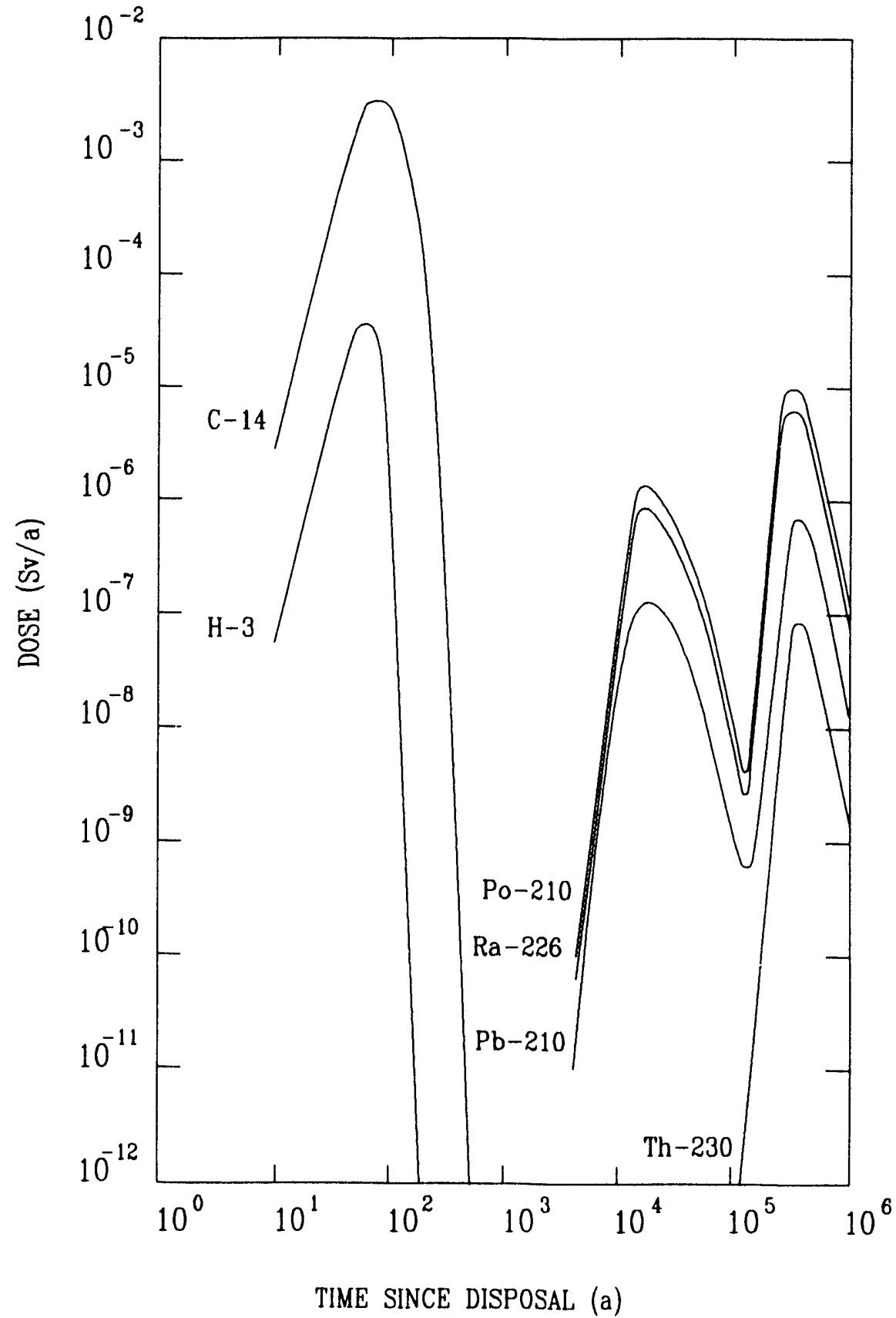

IAEA21

Exhibit 2. (continued). 
COUNTRY: USA

ORGANIZATION: ORNLDOE

PAGE 5 OF 10

DATE $1992-11-30$

\section{RESULTS FOR NSARS TEST CASE 1T: EARTH TRENCH}

\section{TI1. INTRUSION EXPOSURE}

\section{Name of the scenario}

Intruder - construction

Description of the scenario

Intruder constructs a house on the earth trench. The basement of the house intrudes into the waste. Exposure routes include inhalation and external irradiation.

$\underline{\text { Parameter values }}$

Exposure time: Inhalation rate: $500 \mathrm{~h}$

Fraction of year exposed:

$$
8000 \mathrm{~m}^{3} / \mathrm{a}
$$

Mass loading:

Soil Density:

0.057

$1 \times 10^{-6} \mathrm{~kg} / \mathrm{m}^{3}$

$1400 \mathrm{~kg} / \mathrm{m}^{3}$

Table 1TI1. Maximum doses from intrusion exposure, construction

\begin{tabular}{|c|c|c|c|c|c|}
\hline \multirow{2}{*}{$\begin{array}{l}\text { Nuclide } \\
\text { (incl. } \\
\text { daughters) }\end{array}$} & \multicolumn{5}{|c|}{ Individual effective dose equivalent, Sv/a } \\
\hline & Ingest. & Inhal. & Ext. irr. & Radon exp. & Total \\
\hline 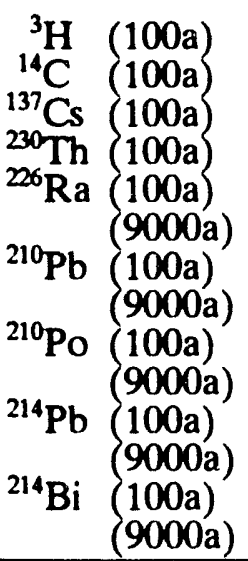 & & $\begin{array}{l}8.2 \times 10^{-13} \\
7.3 \times 10^{-9} \\
1.1 \times 10^{-7} \\
1.1 \times 10^{-3} \\
1.1 \times 10^{-6} \\
2.5 \times 10^{-5} \\
1.3 \times 10^{-5} \\
4.1 \times 10^{-5} \\
8.4 \times 10^{-7} \\
2.6 \times 10^{-5}\end{array}$ & $\begin{array}{l}1.4 \times 10^{-4} \\
3.1 \times 10^{-3} \\
1.0 \times 10^{-3} \\
2.2 \times 10^{-1}\end{array}$ & & $\begin{array}{l}8.2 \times 10^{-13} \\
7.3 \times 10^{-9} \\
8.8 \times 10^{-4} \\
1.1 \times 10^{-3} \\
1.1 \times 10^{-6} \\
2.5 \times 10^{-5} \\
1.3 \times 10^{-5} \\
4.1 \times 10^{-5} \\
8.4 \times 10^{-7} \\
2.6 \times 10^{-5} \\
1.4 \times 10^{-4} \\
3.1 \times 10^{-3} \\
1.0 \times 10^{-3} \\
2.2 \times 10^{-1}\end{array}$ \\
\hline
\end{tabular}

Exhibit 3. Results for NSARS Test Case 1T, Earth Trench: 1TI1 Intrusion Exposure, Construction. 
COUNTRY: USA

ORGANIZATION: ORNL/DOE

PAGE $\quad 6 \quad$ OF 10

DATE $1992-11-30$

\section{RESULTS FOR NSARS TEST CASE 1T: EARTH TRENCH}

\section{TI1. INTRUSION EXPOSURE}

Name of the scenario

Intruder - agriculture

Description of the scenario

Intruder resides in a house on the trench. The intruder has a garden and receives exposure from ingestion of vegetables and related soil, inhalation during gardening and while in the house, and external exposure during gardening and while in the house.

Parameter values

Soil dilution factor:

0.2

Vegetable intake:

$90 \mathrm{~kg} /$ year

Soil intake:

$0.037 \mathrm{~kg} /$ year

Fraction of year spent in garden: $0.01(876 \mathrm{~h})$

Mass Loading:

$$
\begin{aligned}
& 1 \times 10^{-6} \mathrm{~kg} / \mathrm{m}^{3} \text { (garden), } \\
& 1 \times 10^{-7} \mathrm{~kg} / \mathrm{m}^{3} \text { (house) }
\end{aligned}
$$

Fraction of year spent in house: $0.5(4380 \mathrm{~h})$

Table 1T12. Maximum doses from intrusion

\begin{tabular}{|c|c|c|c|c|c|}
\hline \multirow{2}{*}{$\begin{array}{c}\text { Nuclide } \\
\text { (incl. } \\
\text { daughters) }\end{array}$} & \multicolumn{5}{|c|}{ Individual effective dose equivalent, Sv/a } \\
\hline & Ingest. & Inhal. & Ext. irr. & Radon exp. & Total \\
\hline 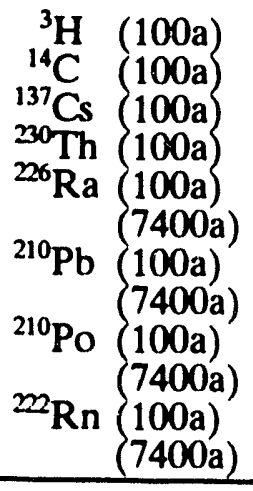 & $\begin{array}{l}7.7 \times 10^{-7} \\
8.0 \times 10^{-5} \\
3.5 \times 10^{-5} \\
3.5 \times 10^{-4} \\
8.9 \times 10^{-4} \\
1.9 \times 10^{-2} \\
1.1 \times 10^{-4} \\
3.4 \times 10^{-3} \\
2.2 \times 10^{-5} \\
6.8 \times 10^{-4}\end{array}$ & $\begin{array}{l}3.7 \times 10^{-12} \\
3.3 \times 10^{-8} \\
1.4 \times 10^{-8} \\
1.4 \times 10^{-3} \\
1.4 \times 10^{-6} \\
3.1 \times 10^{-5} \\
1.6 \times 10^{-6} \\
5.0 \times 10^{-5} \\
1.0 \times 10^{-6} \\
3.2 \times 10^{-5}\end{array}$ & $5.4 \times 10^{-3}$ & $\begin{array}{l}6.5 \times 10^{-3} \\
1.4 \times 10^{-1} \\
\end{array}$ & $\begin{array}{l}7.7 \times 10^{-7} \\
8.0 \times 10^{-5} \\
5.4 \times 10^{-3} \\
1.8 \times 10^{-3} \\
8.9 \times 10^{-4} \\
1.9 \times 10^{-2} \\
1.1 \times 10^{-4} \\
3.4 \times 10^{-3} \\
2.3 \times 10^{-5} \\
7.1 \times 10^{-4} \\
6.5 \times 10^{-3} \\
1.4 \times 10^{-1}\end{array}$ \\
\hline
\end{tabular}
exposure, agriculture

Exhibit 4. Results for NSARS Test Case 1T, Earth Trench: 1TI1 Intrusion Exposure, Agriculture. 
COUNTRY:

USA

ORGANIZATION: ORNLIDOE

PAGE 7 OF 10

DATE 1992-11-30

\section{RESULTS FOR NSARS TEST CASE 1V: ENGINEERED VAULT}

\section{VR. RELEASE TO GEOSPHERE}

Pore velocity ( $v$ ) assumed equal to cap or concrete Darcy velocity $(0.032 \mathrm{~m} / \mathrm{a})$ divided by the porosity of the waste $(0.25)$. Pore velocity was determined to be $0.13 \mathrm{~m} / \mathrm{a}$.

Description of release model

For all nuclides, leach rate was determined from:

$$
\frac{v}{d\left(1+\frac{P}{\theta} k d\right)}
$$

The release rate was equal to the product of the vault activity as a function of time and the leach rate constant.

Parameter values (additional to those specified)

Infiltration in cap was assumed equal to the hydraulic conductivity times the gradient $\left(3.2 \times 10^{-2} \mathrm{~m} / \mathrm{a}\right)$.

Ra-226 and ${ }^{210} \mathrm{~Pb}$ were released at their own rates according to their respective leach rate constants.

Leachate flowrate: $32 \mathrm{~m}^{3} / \mathrm{a}$

Table 1VR. Maximum release rate

\begin{tabular}{ccc}
\hline $\begin{array}{c}\text { Nuclide } \\
\text { (incl. daughters) }\end{array}$ & $\begin{array}{c}\text { Maximum release } \\
\text { rate, Bq/a }\end{array}$ & $\begin{array}{c}\text { Time of } \\
\text { maximum, a }\end{array}$ \\
\hline${ }^{3} \mathrm{H}$ & $1.6 \times 10^{10}$ & 1 \\
${ }^{14} \mathrm{C}$ & $1.6 \times 10^{10}$ & 1 \\
${ }^{27} \mathrm{Cs}$ & $5.3 \times 10^{6}$ & 1 \\
${ }^{230} \mathrm{Th}$ & $5.3 \times 10^{5}$ & 1 \\
${ }^{210} \mathrm{Ra}$ & $1.4 \times 10^{7}$ & 9000 \\
\end{tabular}

Exhibit 5. Results for NSARS Test Case 1V, Engineered Vault: 1VR Release to Geosphere. 
COUNTRY: U.S.A.

ORGANIZATION: ORNL/DOE
PAGE $\frac{8}{1992-11}$ OF $\frac{10}{1-30}$

RESULTS FOR NSARS TEST CASE IV: ENGINEERED VAULT

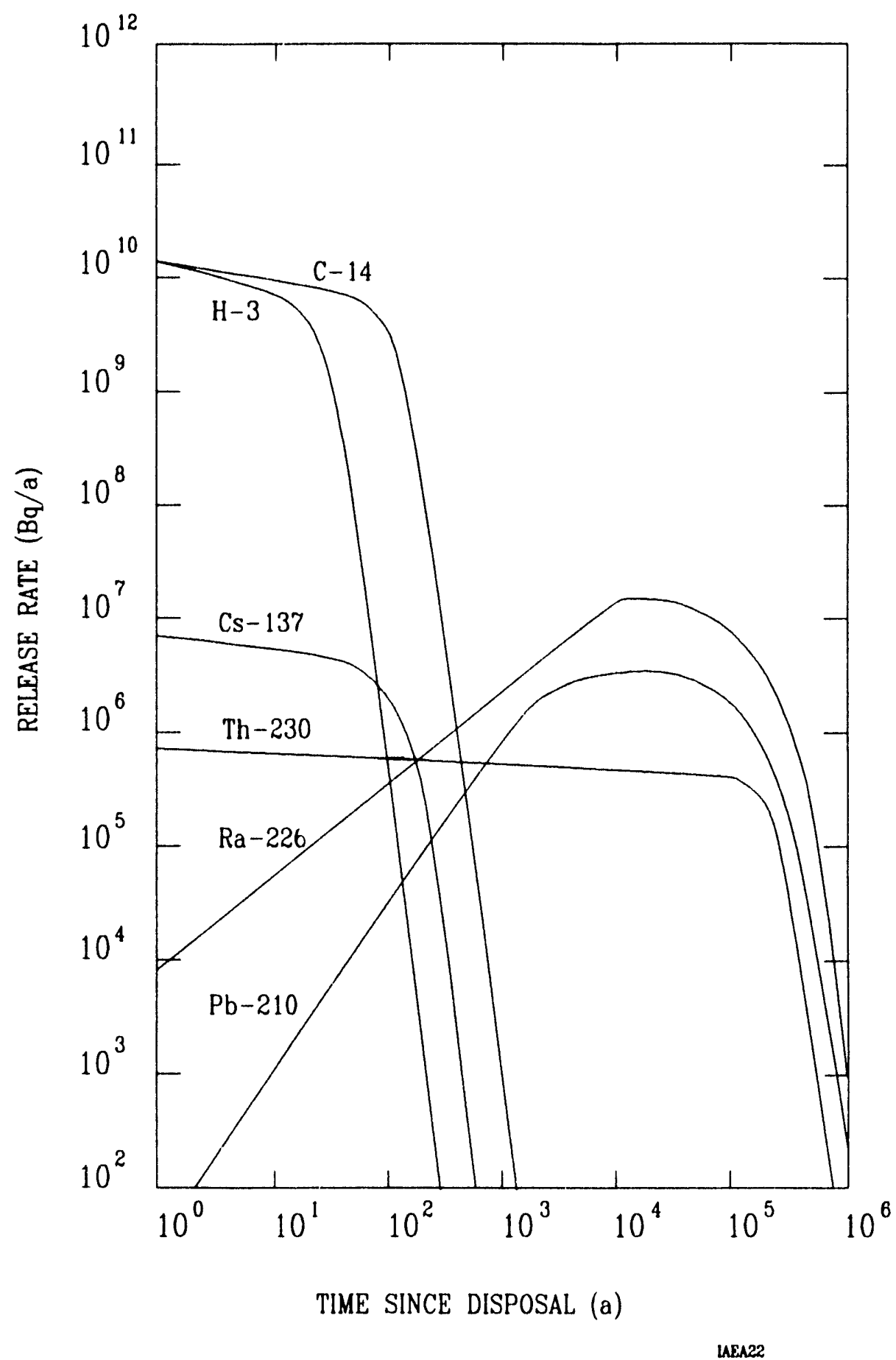

Exhibit 5. (continued). 
COUNTRY:

USA

PAGE 9 OF 10

ORGANIZATION: ORNL/DOE

DATE 1992-11-30

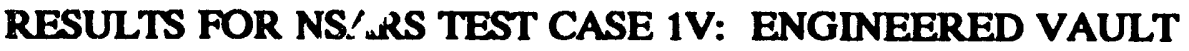

1VW. EXPOSURE TO MAN VIA WELL USE

Description of transport model

Codell analytical model (GRND) for a constant velocity, isotropic, homogeneous aquifer of constant thickness was used.

Parameter values (additional to those specified)

Aquifer thickness is $10 \mathrm{~m}$; it was assumed that the contaminant was vertically mixed to this depth.

Table 1VW. Effective dose equivalent for drinking well water

\begin{tabular}{ccc}
$\begin{array}{c}\text { Nuclide } \\
\text { (incl. daughters) }\end{array}$ & $\begin{array}{c}\text { Maximum dose, } \\
\text { Sv/a }\end{array}$ & $\begin{array}{c}\text { Time of } \\
\text { maximum, a }\end{array}$ \\
\hline${ }^{3} \mathrm{H}$ & $1.7 \times 10^{-6}$ & 40 \\
${ }^{14} \mathrm{C}$ & $5.6 \times 10^{-5}$ & 40 \\
${ }^{137} \mathrm{Cs}$ & $\cdots$ & $\cdots$ \\
${ }^{230} \mathrm{Th}$ & $4.8 \times 10^{-9}$ & $5.0 \times 10^{5}$ \\
${ }^{26} \mathrm{Ra}$ & $3.0 \times 10^{-7}$ & $5.0 \times 10^{5}$ \\
${ }^{210} \mathrm{~Pb}$ & $4.5 \times 10^{-8}$ & $5.0 \times 10^{5}$ \\
${ }^{210} \mathrm{Po}$ & $4.2 \times 10^{-7}$ & $5.0 \times 10^{5}$ \\
\hline
\end{tabular}

Exhibit 6. Results for NSARS Test Case 1V, Engineered Vault: 1VW Exposure to Man via Well Use. 
COUNTRY:

U.S.A.

ORGANIZATION: ORNL/DOE

PAGE $\frac{10}{1992-11-30}$

RESULTS FOR NSARS TEST CASE 1V: ENGINEERED VAULT

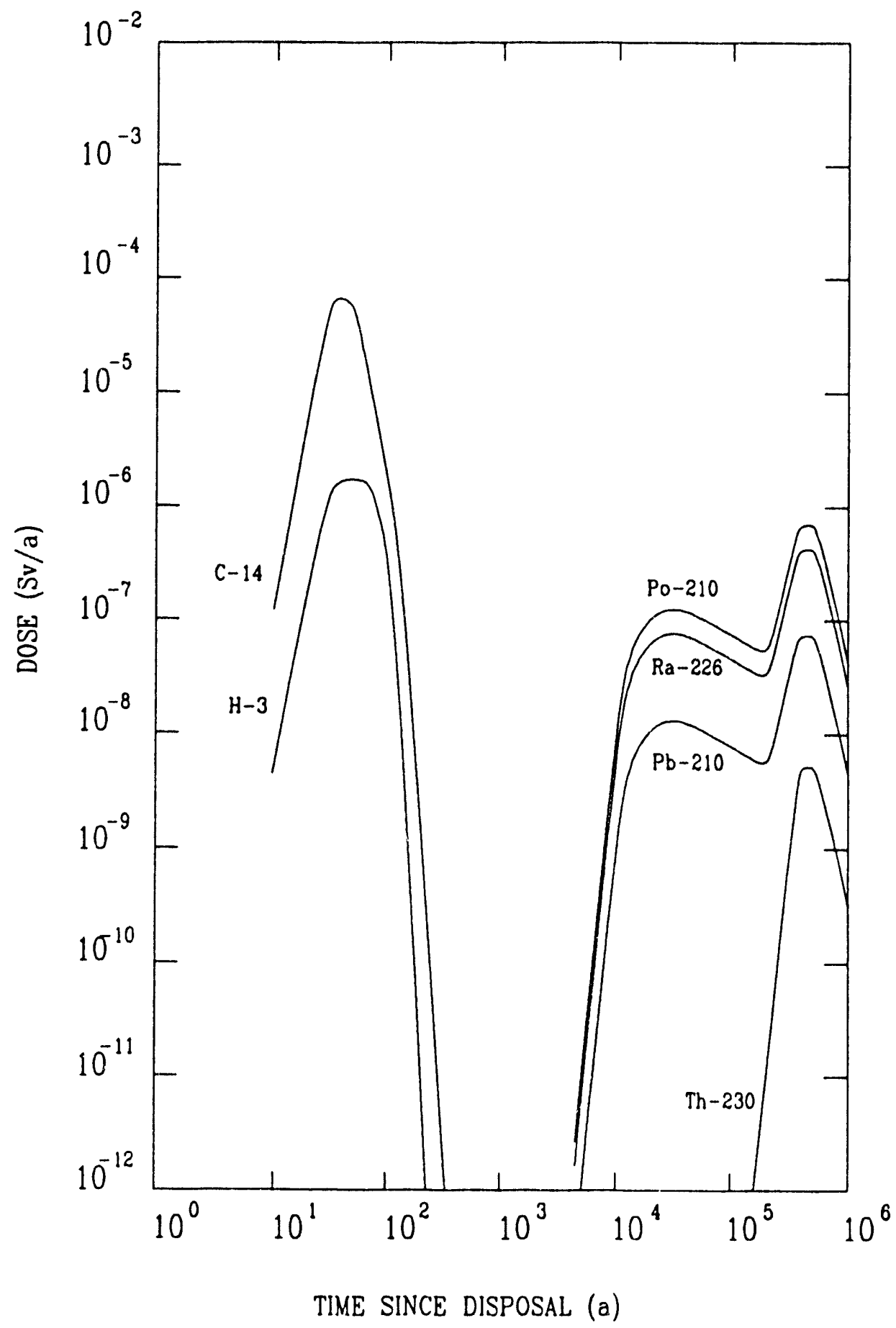

Exhibit 6. (continued). 
are larger than ${ }^{230} \mathrm{Th}$ due to their smaller sorption coefficients. Since the release rates are directly proportional to the leach rate constant, this allows the daughters of ${ }^{230} \mathrm{Th}$ to be released according to their own sorption coefficients.

The drinking water doses for both disposal concepts were determined using an analytical groundwater model with a constant flow rate in one dimension and dispersion in the $x$ and $y$ directions. The radionuclides were assumed to be mixed in the $z$ direction, which is an aquifer thickness of $10 \mathrm{~m}$.

The travel time for a radionuclide from the disposal site to the well, located $500 \mathrm{~m}$ from the disposal site, was determined from the aquifer pore velocity. The aquifer pore velocity was determined from the IAEA information to be $12.6 \mathrm{~m} / \mathrm{a}$. This results in a travel time to the well of approximately $\mathbf{4 0}$ years for radionuclides without sorption. This was the travel time obtained for ${ }^{14} \mathrm{C}$ for both disposal concepts. C-14 has a retardation factor of 1 and a long half-life in relation to the travel time; therefore, the saturated flow analysis correctly predicts the travel time to the well. The doses for ${ }^{226} \mathrm{Ra}$ and daughters appear as two peaks: one from the initial release of ${ }^{226} \mathrm{Ra}$ from the source at its own release rate and the other from ingrowth from ${ }^{230} \mathrm{Th}$ during groundwater transport. The analysis allowed the release of radionuclides at their own rates; however, during groundwater transport the daughter radionuclides were assumed to be transported at the rate of the parent radionuclide. Equilibrium was assumed between the parent radionuclide and the daughter radionuclides, with the concentration for the daughters determined from the concentration of the parent times the ratio of the parent retardation factor to the daughter retardation factor.

Intrusion scenarios were considered only for the earth trench disposal concept since the engineered vault was assumed to be protected by the concrete structures. Two intruder scenarios were considered: the intruder-construction and the intruder-agriculture. In both intrusion scenarios, the source was assumed to have been reduced by decay only, with no loss due to groundwater leaching. This was considered a conservative assumption since the maximum pore velocity was used in the groundwater analysis and may have reduced the source inventory for the intruder. The information in the proforma sheets indicate that the intruder-agriculture 
scenario results in doses that are higher than the intruder-construction. This is reasonable since the intruder-agriculture scenario is an extension of the intruderconstruction scenario, except that the intruder in the agriculture scenario is exposed to several additional pathways.

\section{SUMMARY}

Doses from drinking water from a well were evaluated for both repository designs. The drinking water doses to an off-site individual for the earth trench repository were approximately an order of magnitude larger than those evaluated for the engineered vault repository.

The intruder scenario was assumed to be reasonable only for the earth trench scenario. Therefore, intruder dose calculations were not performed for the engineered repository. Two intruder scenarios were considered for the earth trench repository: the intruder-construction and the intruder-agriculture. The intruder-agriculture scenario resulted in doses that were orders of magnitude higher for several radionuclides when compared to the intruder-construction scenario. This was due to the addition of the ingestion pathway from vegetables taken from the garden in the intruder-agriculture scenario. The most significant result observed from the intruder scenario involved the ingrowth of progeny from the ${ }^{230}$ Th decay chain that resulted in peak doses several thousand years after institutional control. In addition, the dose from ${ }^{222} \mathrm{Rn}$ dominated total dose to the intruder in the agriculture scenario. This indicated that the disposal of small quantities of ${ }^{238} \mathrm{U}$ or ${ }^{230} \mathrm{Th}$ would result in significant doses to an intruder from the ingrowth of ${ }^{2 m} \mathrm{Rn}$. 


\section{REFERENCES}

Anspaugh, L. R., J. H. Shinn, P. L. Phelps, and N. C. Kennedy. 1975.

Resuspension and redistribution of plutonium in soils. Health Physics, 29:571.

Baes, C. F., III, and R. D. Sharp. 1983. A proposal for estimation of soil leaching consultants for use in assessment models. Journal of Environmental Quality, 12:17.

Codell, R. B., K. T. Key, and G. Whelan. 1981. A Collection of Mathematical Models for Dispersion in Surface Water and Groundwater. NUREG-0868. U. S. Nuclear Regulatory Commission, Washington, D.C.

Culot, M. V. J., H. G. Olson, and D. J. Schiager. 1976. Effective diffusion coefficient of radon in concrete, theory and method for field measurement. Health Physics, 30:(263-270).

Gilbert, T. L., C. Yu, Y. C. Yuan, A. J. Zielen, M. J. Jusko, and A. Wallo III. 1989. A Manual for Implementing Residual Radioactive Material Guidelines. ANL/ES-160, DOE/CH/8901, Argonne National Laboratory, Chicago, IL.

ICRP. 1979. Limits for Intakes of Radionuclides by Workers. Publication 30. International Commission on Radiological Protection, Pergamon Fress, Oxford.

ICRP. 1983. Radionuclide Transformation, Energy and Intensity of Omissions. Publication 38. International Commission on Radiological Protection, Pergamon Press, Oxford. 
ICRP. 1987. Lung Cancer Risk from Indoor Exposures to Radon Daughters. Publication 50. International Commission on Radiological Protection, Pergamon Press, Oxford.

Kirchner, T. B. 1990. TIME-ZERO: The Integrated Modeling Environment. Quaternary Software, Inc., Fort Collins, Colo.

Kocher, D. C. 1980. Effects of indoor residence on radiation doses from routine releases of radionuclides to the atmosphere. Nuclear Technology, 48:171.

Kocher, D. C. 1981. Radioactive Decay Data Tables. DOE/TIC-11026. U. S. Department of Energy, Washington, D.C.

Kocher, D. C., and A. L. Sjoreen. 1985. Dose-rate conversion factors for photon emitters in soil. Health Physics, 48:193.

Kocher, D. C., and F. R. O'Donnell. 1987. Consideration on a De Minimus Dose and Disposal of Exempt Concentrations of Radioactive Wastes. ORNL/TM10338. Oak Ridge National Laboratory, Oak Ridge, Tenn.

Napier, B. A., R. A. Peloquin, W. E. Kennedy, Jr., and S. M. Neuder. 1984. Intrude. Dose Pathway Analysis for the Onsite Disposal of Radioactive Waste: The OSITE/MAXII Computer Program. NUREG/CR-3620. PNL-4054. Pacific Northwest Laboratory, Richland, Wash.

$\mathrm{Ng}$, Y. C. 1982. A review of transfer factors for assessing the dose from radionuclides in agricultural products. Nuclear Safety, 23:57.

Ng, Y. C., C. S. Colsher, and S. E. Thompson. 1982. Soil-to-Plant Concentration Factors for Radiological Assessments. NUREG/CR-2975, UCID-19463. Lawrence Livermore Laboratory, Livermore, Calif. 
Oztunali, O. I., G. C. Re, P. M. Moskowitz, E. D. Picazo, and C. J. Pitt. 1981.

Data Base for Radioactive Waste Management. NUREG/CR-1759, Vol. 3.

Dames and Moore, Inc., U. S. Nuclear Regulatory Commission, Washington, D.C.

Peterson, H. T., Jr. 1983. Terrestrial and Aquatic Food Chain Pathways. Chapter 5 in Radiological Assessment, J. E. Till and H. R. Meyer, eds. NUREG/CR3332, ORNL-5968. U. S. Nuclear Regulatory Commission and Oak Ridge National Laboratory, Oak Ridge, Tenn.

Rogers, V. C., K. K. Nielson, and D. R. Kalkwarf. 1984. Radon Attenuation Handbook for Uranium Mill Tailings Cover Design. NUREG/CR-3533. U. S. Nuclear Regulatory Commission, Washington, D.C.

Rogers, V. C., and C. Hung. 1987. PATHRAE-EPA: A Low-Level Radioactive Waste Environmental Transport and Risk Assessment Code. EPA 520/1-87028. U. S. Environmental Protection Agency, Washington, D.C.

U.S.DOE. 1986. Development of Threshold Guidance. Draft. DOE/LLW-40T. U. S. Department of Energy, Washington, D.C.

U.S.DOE. 1988. External Dose-Rate Conversion Factors for Calculation of DOSE to the Public. DOE/EH-0070. U. S. Department of Energy, Washington, D.C.

U.S.NRC. 1977. Calculation of Annual Doses to Man from Routine Releases of Reactor Effluents for the Purpose of Evaluating Compliance with 10 CFR Part 50. Regulatory Guide 1.109. U. S. Nuclear Regulatory Commission, Washington, D.C. 


\section{ACRONYMS AND INITIALISMS}

IAEA

NSARS
International Atomic Energy Agency

Near-Surface Radioactive Waste Disposal Safety

Assessment Reliability Study

International Commission of Radiological Protection 
ORNL/TM-12101

\section{INTERNAL DISTRIBUTION}

$\begin{aligned} 1 . & \text { B. A. Berven } \\ 2 . & \text { D. K. Halford } \\ 3 . & \text { P. M. Kearl } \\ 4-8 . & \text { D. C. Kocher } \\ 9 . & \text { A. D. Lasse } \\ 10-19 . & \text { C. A. Little } \\ 20-24 . & \text { L. M. McDowell-Boyer } \\ 25 . & \text { P. T. Owen }\end{aligned}$

26 - 30. D. J. Thorne

31. R. E. Swaja

32. Central Research Library

33 - 34. Laboratory Records

35. Laboratory Records - RC

36. ORNL Patent Section

37. ORNL Technical Library, Y-12

\section{EXTERNAL DISTRIBUTION}

38. J. R. Cook, Westinghouse Savannah River Company, Savannah River Site, P.O. Box 616, Aiken, SC, 29802

39. G. J. Duggan, U.S. Department of Energy, EM-351, Trevion II, Washington, D.C. 20585-0002

40. R. A. Hiergesell, Westinghouse Savannah River Company, Savannah River Site, P.O. Box 616, Aiken, SC 29802

41. S. R. Reed, Westinghouse Savannah River Company, Savannah River Site, P.O. Box 616, Aiken, SC, 29802

42 - 46. E. K. Roemer, Oak Ridge Institute of Science and Education, P.O. Box 2567, Grand Junction, CO 81502

47. E. L. Wilhite, Westinghouse Savannah River Company, Savannah River Site, P.O. Box 616, Aiken, SC, 29802

48. Office of Assistant Manager, Energy Research and Development, Oak Ridge Operations Office, P.O. Box 2001, Oak Ridge, TN 37831-8600

49 - 50. Office of Scientific and Technical Information, U.S. Department of Energy, P.O. Box 62, Oak Ridge, TN 37831 

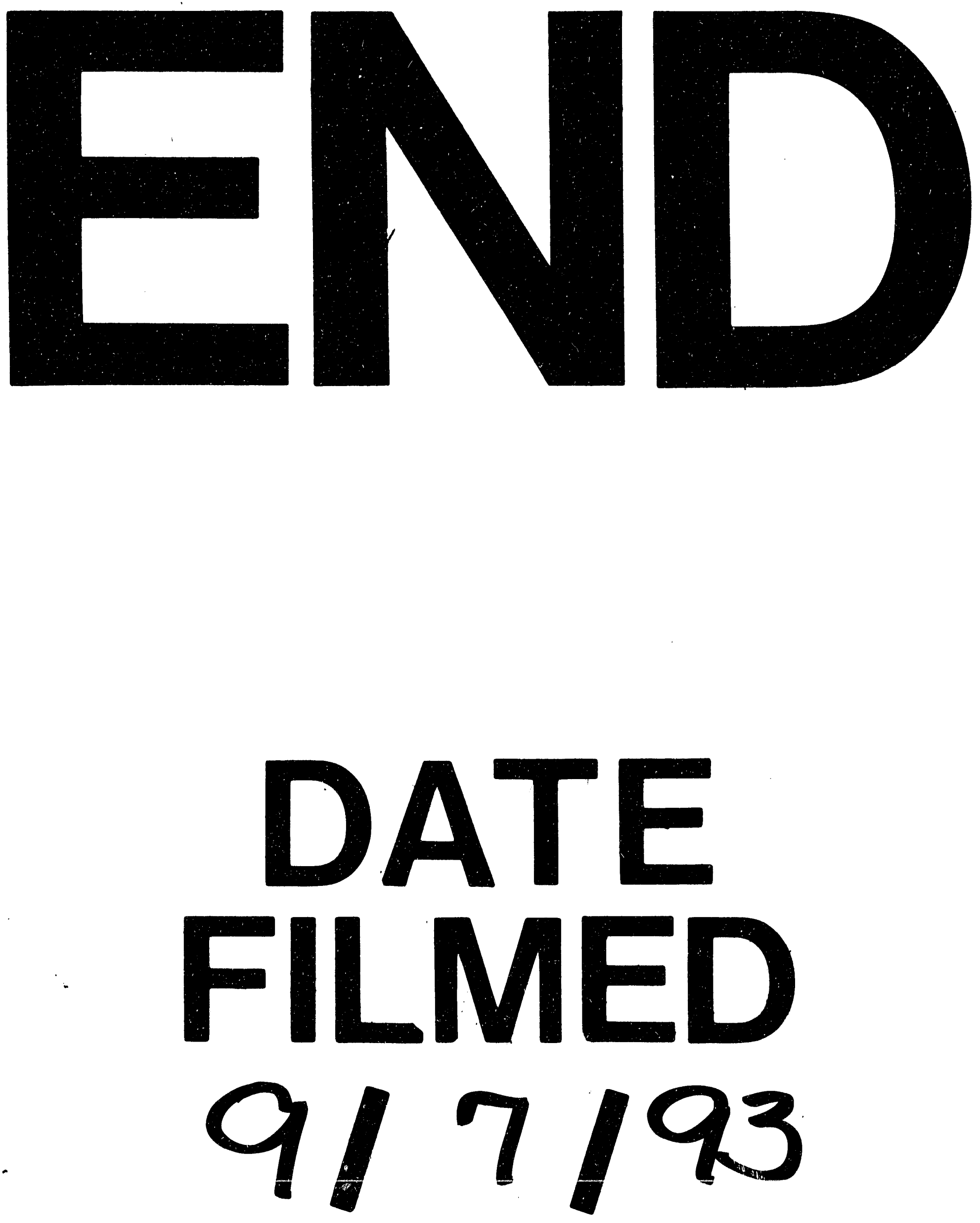
